NBER WORKING PAPER SERIES

\title{
LIQUIDITY CONSTRAINTS AND CONSUMER BANKRUPTCY: EVIDENCE FROM TAX REBATES
}

\author{
Tal Gross \\ Matthew J. Notowidigdo \\ Jialan Wang \\ Working Paper 17807 \\ http://www.nber.org/papers/w17807
}

\author{
NATIONAL BUREAU OF ECONOMIC RESEARCH \\ 1050 Massachusetts Avenue \\ Cambridge, MA 02138 \\ February 2012
}

We are grateful to Ben Keys, Erik Hurst, Neale Mahoney, Nick Souleles, and seminar participants at the University of California at Los Angeles, University of Illinois, University of Miami, the Olin School of Business, the Federal Reserve Bank of Philadelphia, and Columbia University for useful feedback. We thank Ido Moskovich and Anthony Vashevko for helpful research assistance. The views expressed herein are those of the authors and do not necessarily reflect the views of the National Bureau of Economic Research.

NBER working papers are circulated for discussion and comment purposes. They have not been peerreviewed or been subject to the review by the NBER Board of Directors that accompanies official NBER publications.

(C) 2012 by Tal Gross, Matthew J. Notowidigdo, and Jialan Wang. All rights reserved. Short sections of text, not to exceed two paragraphs, may be quoted without explicit permission provided that full credit, including $\odot$ notice, is given to the source. 
Liquidity Constraints and Consumer Bankruptcy: Evidence from Tax Rebates

Tal Gross, Matthew J. Notowidigdo, and Jialan Wang

NBER Working Paper No. 17807

February 2012

JEL No. H31,K35

\section{ABSTRACT}

This paper estimates the extent to which legal fees prevent liquidity-constrained households from declaring bankruptcy. To do so, it studies how the 2001 and 2008 tax rebates affected consumer bankruptcy filings. We exploit the randomized timing of the rebate checks and estimate that the rebates caused a significant, short-run increase in consumer bankruptcies in both years, with larger effects in 2008 when the rebates were more generous and more widely distributed. Using hand-collected data from individual bankruptcy petitions, we document that the rebates caused an increase in the average liabilities and the liabilities-to-income ratios of filers.

Tal Gross Department of Health Policy and Management Mailman School of Public Health Columbia University 600 West 168th Street, Sixth Floor

New York, NY 10032

tg2370@columbia.edu

Matthew J. Notowidigdo

University of Chicago

Booth School of Business

5807 South Woodlawn Avenue

Chicago, IL 60637

and NBER

noto@chicagobooth.edu
Jialan Wang

Olin Business School

Washington University in St. Louis 208 Simon Hall

1 Olympian Way

St. Louis, MO, 63130

jialan.wang@wustl.edu 


\section{Introduction}

Over the past three decades, consumer bankruptcy rates have tripled. As of the late 1990s, nearly ten percent of American households had declared bankruptcy (Stavins, 2000). By 2001, over 1.3 percent of American households were filing for bankruptcy every year (Zywicki, 2005). In an attempt to slow the increase in bankruptcies, the 2005 Bankruptcy Abuse Prevention and Consumer Protection Act (BAPCPA) raised the barriers consumers must overcome in order to file for bankruptcy. The BAPCPA requires that bankruptcy filers undergo mandatory credit counseling at their own expense. Furthermore, the act raises the legal and administrative fees that households have to pay in order to declare bankruptcy. These "entrance fees" for bankruptcy increased from an average of $\$ 921$ before the reform to an average of $\$ 1,477$ after the reform (GAO, 2008).

While there exists a divisive debate over these entrance fees (Zywicki, 2005; Mann and Porter, 2010), little empirical research has estimated their effect. Unfortunately, economic theory provides little guidance, as the welfare consequences of entrance fees are theoretically ambiguous. On the one hand, fees may act as an ordeal mechanism, screening out households who stand to gain little from filing for bankruptcy (Nichols and Zeckhauser, 1982). On the other hand, the fees may prevent liquidity-constrained households from filing for bankruptcy, and those households may benefit the most from filing.

In this paper, we find that a significant fraction of bankruptcy filers are liquidityconstrained. We exploit plausibly exogenous variation in liquidity induced by the 2001 and 2008 income tax rebates. The rebates were distributed over 9-10 week periods in both years, and households received between $\$ 300$ and $\$ 1,200$. The date households received their rebates was effectively randomly assigned, which allows us to estimate the causal effect of a one-time, anticipated increase in liquidity on consumer bankruptcy filings.

We find that the tax rebates led to a significant, short-run increase in consumer bankrupt- 
cies. Total bankruptcies increased by roughly 2 percent after the 2001 rebates, and by 7 percent after the 2008 rebates. The increase in bankruptcies was driven entirely by Chapter 7 filings, which is consistent with the existence of liquidity constraints. ${ }^{1}$ We find no evidence that the increase consisted of bankruptcies that otherwise would not have occurred. Instead, the rebates likely allowed households to file months earlier than they otherwise would have been able to file.

To interpret our results, we develop a simple model of consumer bankruptcy. ${ }^{2}$ The model is motivated by the relevant case law regarding how bankruptcy courts treated the tax rebates. It suggests that tax rebates should only affect the filing decisions of liquidityconstrained households. The model allows us to translate our empirical results into an estimate of the share of households who wish to file for bankruptcy but cannot afford to do so. Combining our model and empirical results, we conclude that 2.0 percent of filers in 2001 and 3.8 percent of filers in 2008 could not afford to file for bankruptcy in the absence of the tax rebates. The larger share in 2008 is likely driven by the larger average value of the rebate checks as well as the more severe recession, which likely increased the number of liquidity-constrained households.

Our results are consistent with existing evidence on household liquidity constraints (Lusardi et al., 2011), and our paper contributes to the literature on the economic effects of these constraints. Liquidity constraints have been shown to cause excessive consumption responses to transitory changes in income (Shapiro and Slemrod, 2003; Souleles, 1999; Hsieh, 2003; Stephens, 2003), limit investment in human capital (Dynarski, 2003), and amplify the behavioral response to unemployment insurance benefits (Chetty, 2008). ${ }^{3}$ Additionally, liquidity

\footnotetext{
${ }^{1}$ Households can file for bankruptcy either under Chapter 7 or Chapter 13. Chapter 7 filers are more likely to be liquidity-constrained since they have lower incomes and fewer assets. Moreover, the majority of Chapter 7 legal fees must be paid in advance of filing, while Chapter 13 legal fees can be paid gradually after filing.

${ }^{2}$ See Wang and White (2000) for a related model.

${ }^{3}$ Liquidity constraints also affect sub-prime mortgage defaults in the months following lump-sum property tax payments (Anderson and Dokko, 2011). By contrast, Hurst and Lusardi (2004) do not find clear evidence
} 
constraints likely play an important role in the optimal design of social insurance programs (Chetty, 2008; Hansen and İmrohoroğlu, 1992). Since consumer bankruptcy functions-at least in part - as a social insurance program, our paper is broadly related to the literature on the role of ordeal mechanisms and entrance fees in the optimal design of social insurance programs (Nichols and Zeckhauser, 1982). We discuss below how our estimates shed light on the welfare consequences of changing the structure of the consumer bankruptcy system.

Our paper is also part of a growing literature on the economic effects of tax rebates. Most related papers focus on the effects of the tax rebates on consumption and expenditures (Johnson et al., 2006; Agarwal et al., 2007; Shapiro and Slemrod, 2003; Bertrand and Morse, 2009), while other studies have estimated the effect of the tax rebates on mortality and morbidity (Evans and Moore, 2011; Gross and Tobacman, 2011). To our knowledge, no previous studies have focused on the effect of the tax rebates on take-up of social insurance programs or consumer bankruptcy.

The tax rebates were designed to stimulate the economy. Our results therefore shed light on how the rebates actually stimulated consumption. Previous studies have concluded that households consumed a moderate-to-large share of the rebates (Johnson et al., 2006; Parker et al., 2010). Our results suggest that many households used the rebates to file for bankruptcy. Moreover, households may increase consumption by a great deal after bankruptcy (Filer and Fisher, 2005; Zhu, 2011). Thus our results suggest that-for some households - the rebates may have increased short-run consumption by more than the amount of the rebates themselves. In this sense, reducing the barriers to bankruptcy may be a particularly effective economic stimulus, as the timely discharge of household debt may increase household consumption substantially (Mian et al., 2011).

The remainder of the paper proceeds as follows. The next section provides background on the tax rebates and describes the bankruptcy data that we have compiled. Section 3 outlines that liquidity constraints restrict entry into entrepreneurship. 
a theoretical model that explains how the tax rebates can affect bankruptcy rates. Section 4 demonstrates how the rebates affected the number of bankruptcies. Section 5 describes how the characteristics of the filers changed after the rebates. Section 6 discusses the alternative explanations for our findings and their policy implications. Section 7 concludes.

\section{Background on the Bankruptcy Data and the Tax Rebates}

In order to estimate the impact of the rebates on bankruptcy rates, we have compiled a unique data set based on the Public Access to Court Electronic Records system. ${ }^{4}$ Our sample consists of all consumer bankruptcy filings in the 72 courts that agreed to grant us full electronic access to their dockets. Figure 1 presents a map of our sample coverage. We verified that the data match aggregate counts of bankruptcies reported by the Administrative Office of the Us courts.

Table 1 compares the characteristics of districts in our sample to those not in our sample. The sample covers roughly 74 percent of bankruptcies in the United States and 73 percent of the population. Coverage remains consistent across our sample period, which extends from 1998 to 2008. The districts in the sample have populations with slightly lower income, less college education, and a lower unemployment rate.

The tax rebates were disbursed as part of the economic stimulus bills passed by Congress in 2001 and 2008, and were specifically designed to stimulate the economy during the ongoing recessions. ${ }^{5}$ The Internal Revenue Service (IRS) sent the rebate checks on a schedule determined by the head-of-household's social security number (SSN). Table 2 presents the dates on which checks were sent. We include in our sample all bankruptcies that were filed at most 30 weeks prior to the date that checks were sent and at most 40 weeks after that

\footnotetext{
${ }^{4}$ We are grateful to Tom Chang for providing some of the computer code necessary to parse the electronic records.

${ }^{5}$ The rebates were mandated by the Economic Growth and Tax Relief Reconciliation Act of 2001 and the Economic Stimulus Act of 2008.
} 
date. $^{6}$ In 2001, social security numbers were divided into ten equally-sized groups. Checks were mailed from the $20^{\text {th }}$ of July through the $21^{\text {st }}$ of September. The payments ranged from $\$ 300-\$ 600 .^{7}$ In 2008 , households could elect to receive their stimulus payments via either check or direct deposit. As indicated in the third panel of Table 2, there were only three dates on which direct-deposit transfers were made. Roughly 40 percent of households elected to receive their rebate checks via direct deposit (Parker et al., 2010). The rebate payments were higher in 2008 than in 2001 , ranging from $\$ 300-\$ 600$ for single filers to $\$ 600-\$ 1200$ for couples. $^{8}$

Figure 2 summarizes the bankruptcy rates by two-digit SSN group. Reassuringly, the figure demonstrates that there is no systematic variation in bankruptcy rates across SSN groups in the months leading up to the rebates. ${ }^{9}$

\section{Conceptual Framework}

This section presents a simple model that describes how an increase in liquidity can affect bankruptcy rates. The model suggests that liquidity-constrained households are the only households who change their filing behavior after the rebates. Such households can only file after receiving the rebates. Thus bankruptcy rates increase after the rebates are distributed, and the increase is driven by liquidity-constrained households.

\footnotetext{
${ }^{6}$ We restrict the sample by time relative to when the checks were sent, so that we have the same number of observations for each group. The results are similar when we restrict by absolute, calendar time and are also similar when we extend the sample window.

${ }^{7}$ Individual tax filers with no dependents could receive up to $\$ 300$ through the rebate, single parents a maximum of $\$ 500$, and married couples jointly filing could receive $\$ 600$. To receive the full amount, a single taxpayer had to have earned at least $\$ 6,000$ in taxable income in 2000 while a married couple jointly filing had to have earned at least $\$ 12,000$ in taxable income.

${ }^{8}$ If a filer's 2007 tax return indicated over $\$ 3,000$ in qualifying income, the filer was eligible for at least the minimum payment based on the following general guidelines: $\$ 300$ to $\$ 600$ for individuals, $\$ 600$ to $\$ 1,200$ for joint filers, and $\$ 300$ for each qualifying child.

${ }^{9}$ An $F$-test fails to reject the hypothesis that the bankruptcy rates are equal across all groups with a $p$-value of 0.726 in 2001 and 0.864 in 2008.
} 


\subsection{Model Assumptions}

Consider the following three-period model. In period 0, households borrow an exogenous amount of debt, $B$. We assume that debt is exogenous because of our empirical setting. All households eventually receive the rebate within a short window of time, so neither the amount nor maturity of their debt should depend on the timing of the rebates.

In period 1 , households' wealth, $W \sim f(w)$, is realized. In addition, households anticipate receiving the rebate, with value $I$, in period 2 . Households can decide to file in period 1 , in period 2, or not at all. Households consume all of their wealth net of debt and bankruptcy costs at the end of period $2 .^{10}$

Households file for bankruptcy when it is financially beneficial to do so, even if they have the ability to repay their debts (Fay et al., 2002). Specifically, households decide whether and when to file by maximizing consumption in period 2 subject to liquidity constraints. If a household declares bankruptcy, it pays a fixed filing fee, $c$, and loses a share $1-e$ of its wealth. The parameter $e$ captures the generosity of the exemptions provided by the bankruptcy court. ${ }^{11}$ A larger value of $e$ means that a larger share of the household's wealth is exempt and does not need to be turned over to the bankruptcy court during a bankruptcy filing. Once the household has filed for bankruptcy, it is absolved of its debts. ${ }^{12}$

A key assumption of the model involves how the bankruptcy court treats the filers' tax rebates. We assume that the tax rebate is treated the same whether the household files in period 1 or in period 2, and we further assume that the rebate is treated identically

\footnotetext{
${ }^{10} \mathrm{We}$ assume no consumption takes place in period 1 . Including consumption in period 1 would not qualitatively change our results. It would, however, introduce another mechanism whereby some low-wealth households that could technically afford to file would choose to file for bankruptcy in period 2 rather than in period 1 due to the high marginal utility of consumption in period 1 .

${ }^{11}$ In practice, exemptions are governed by both federal and state bankruptcy law. Exemption levels vary widely by state and have been relatively stable at the state level since the early twentieth century (Mahoney, 2010; Gropp et al., 1997).

${ }^{12}$ Bankruptcy in this model is a composite of Chapter 7 and Chapter 13 bankruptcy. While in practice Chapter 13 filers repay their debts based on a three to five year schedule, our framework can capture this by setting the present value of repayments to $1-e$ times wealth net of legal fees.
} 
to the rest of the household's wealth. This assumption implies that households will not strategically manipulate their filing date to try to shield their rebate from the courts. The relevant case law strongly supports this assumption. ${ }^{13}$ If some households nonetheless choose to file before receiving their rebates in an attempt to prevent them from becoming part of the estate, then we would underestimate the percentage of constrained filers. We discuss this possibility below. But given the assumptions above, consumption is equal to $e \cdot(W+I-c)$ if a household decides to file for bankruptcy and $W+I-B$ otherwise.

\subsection{Bankruptcy Filing Decisions}

When deciding whether or not to file for bankruptcy, households face the following constraint. The filing fee, $c$, must be paid in advance, so it must be the case that $W>c$ if the household declares bankruptcy in period 1 and $W+I>c$ if the household declares bankruptcy in period 2. This assumption is particularly relevant for Chapter 7 filings. Court fees of approximately $\$ 300$ are paid in advance for both Chapter 7 and 13 filings. Legal fees for Chapter 7 are almost always paid in advance, while those for Chapter 13 are often paid gradually, through the filer's payment plan.

Household filing behavior depends on the level of realized wealth in period 1 . We can divide households into several groups. Some households have sufficient wealth that they do not file for bankruptcy at all. Such wealthy households are those for which

$$
W+I-B \geq e \cdot(W+I-c) \Rightarrow \quad W \geq \frac{B-e \cdot c-I \cdot(1-e)}{1-e}
$$

Other households file for bankruptcy because it is financially advantageous to do so. The wealth of such households must satisfy two constraints. First, they are able to pay the filing

\footnotetext{
${ }^{13}$ Several court cases (in re Rivera, in re Lambert, in re Howell, and in re Alguires) have established that for bankruptcies filed after the passage of the two stimulus acts, the tax rebates become property of the bankruptcy estate and are subject to normal rules governing other cash assets.
} 
fee in period 1 and in period 2, thus $W>c$. Second, it is in their economic interest to file for bankruptcy. Such households then have wealth that satisfies:

$$
c<W<\frac{B-e \cdot c-I \cdot(1-e)}{1-e} .
$$

These households are indifferent between filing in period 1 versus filing in period 2. Consistent with the characteristics of a typical bankruptcy, we assume that $B$ is large relative to $c$ so that there exist households within this range of wealth. Because $B$ is large relative to $c$ and the bankruptcy court treats the rebate as identical to other assets, a household that can pay its debts by definition can also afford the filing fee. Therefore, there is no incentive for an unconstrained household to manipulate its filing date. Any change in filing rates between period 1 and period 2 will not be due to such households.

Finally, there exist households whose wealth is less than their debts but that do not have enough wealth to file in period $1 .{ }^{14}$ Such liquidity-constrained households cannot borrow to pay the filing fee in period 1, and so must wait until period 2 to file for bankruptcy. By definition, then, such households have wealth that satisfies:

$$
c-I<W<c
$$

These households can only afford to file in period 2. Figure 3 shows how equations (1) through (3) divide households into groups based on realized wealth. ${ }^{15}$

\footnotetext{
${ }^{14} \mathrm{~A}$ final type of household is of little interest, given our empirical setting. Households with wealth $W<c-I$ have so little wealth that they cannot afford the filing fee either in period 1 or in period 2. These households will remain constrained and unable to file. They will be unaffected by the rebates and we will not observe them in the data.

${ }^{15}$ The value $c-I$ is non-negative as long as the costs of filing are greater than the value of the rebates. The value of the rebates were, at most, $\$ 600$ in 2001 and $\$ 1,200$ in 2008. In contrast, average bankruptcy costs are estimated at $\$ 1,477$ in 2007 (GAO, 2008).
} 


\subsection{Predictions of the Model}

The model implies that only liquidity-constrained households change the date of their bankruptcy based on the tax rebates. Such households can only afford to file after receiving their rebate checks.

The model also yields a direct interpretation of our empirical estimates. Let $X$ be the share of households that are unconstrained and declare bankruptcy, and let $Y$ be the share of households that are unable to file at time 1 but can file at time 2 :

$$
\begin{aligned}
X & =\int_{c}^{\frac{B-e \cdot c-I(1-e)}{1-e}} f(W) d W \\
Y & =\int_{c-I}^{c} f(W) d W .
\end{aligned}
$$

Since unconstrained filers are indifferent between filing in period 1 or in period 2 , we assume that half file in each period. The regressions below measure the percent change in bankruptcies after the tax rebates are sent. In the simple case where all households receive tax rebates, this empirical estimate $\beta$ is the share of households filing in period 2 that are constrained filers. The model thus suggests that

$$
\beta=\frac{Y}{\frac{1}{2} \cdot X} .
$$

By relaxing one of the model's key assumptions, we find that our empirical results may underestimate the true fraction of constrained households. Consistent with several legal decisions, the model assumes that courts treat the rebate checks as a part of the bankruptcy estate regardless of whether households file in period 1 or period 2. However, suppose that some households are unaware of this and choose to file at period 1 in an effort to hide the rebates from the court. In this case, the share of households that are unconstrained and file at period 1 would be equal to $\gamma \cdot X$, where $\gamma>\frac{1}{2}$. In this case, the empirical estimates would 
equal:

$$
\beta=\frac{Y-(1-\gamma) \cdot X}{\gamma \cdot X}<\frac{Y}{\frac{1}{2} \cdot X}
$$

Our empirical results would therefore underestimate the fraction of filers who are constrained. Thus, to the extent that households misperceive the laws regarding the treatment of rebates under bankruptcy, our regressions will provide a lower bound for the share of bankruptcy filers who are liquidity constrained.

Additionally, not all households received rebate checks. Assume that a fraction $\lambda$ of households receive rebate checks. If we assume that households that received rebate checks are otherwise identical to households that did not, then our empirical estimate equals:

$$
\beta=\frac{\lambda \cdot Y}{\frac{1}{2} \cdot X}
$$

We can use equation (6) to translate our empirical estimates $(\beta)$ into an estimate $s=$ $Y /(X+Y)$, the share of households who wish to file for bankruptcy but cannot afford to do so in the absence of the rebate. Equation (6) suggests that $s=Y /(X+Y)$ can be re-written as follows:

$$
s=\frac{\beta}{\beta+2 \lambda} .
$$

We use this expression to translate our regression estimates into estimates of $s$.

\section{The Effect of the Tax Rebates on Bankruptcies}

This section presents our main empirical results. We first describe how the bankruptcy rate changed after the tax rebates were distributed. We then describe how the rebate effect evolved over time. 


\subsection{The Change in the Bankruptcy Rate After the Rebates}

The way in which both the 2001 and 2008 tax rebates were distributed lends itself to a simple difference-in-difference empirical framework. For the 2001 sample, we construct aggregate counts of bankruptcies by two-digit SSN group $(g)$ and week $(w)$, and estimate the following regression:

$$
y_{g w}=\beta \cdot I\{\text { After Check Sent }\}_{g w}+\alpha_{g}+\alpha_{w}+\varepsilon_{g w}
$$

The outcome $y_{g w}$ is either the number of bankruptcies in group $g$ and week $w$ or its logarithm, and $\alpha_{g}$ and $\alpha_{w}$ are group and week fixed effects, respectively. The indicator function $I\{\text { After Check Sent }\}_{g w}$ is equal to unity starting one week after checks are sent for group $g$, and zero otherwise. For the 2008 sample, we include an additional indicator function to control for whether the SSN group has been given its direct deposit.

Panel A of Table 3 presents estimates of this regression for the 2001 rebates, while panel B presents estimates for 2008. The first two columns present results when the level and the logarithm of Chapter 7 bankruptcies is the outcome of interest, respectively. Both columns suggest a significant increase in Chapter 7 filings after the rebates were distributed. In 2001, each two-digit SSN group experienced an average of 5.6 additional bankruptcies per week. The estimates in column two indicate a 3.8 percent increase in bankruptcies after the rebates.

Panel B demonstrates that this effect was larger in 2008. The bankruptcy rate increased by 5.1 percent after the 2008 rebate checks were sent. But bankruptcies also increased by 6.2 percent after direct deposits were made. The total increase in bankruptcies after the 2008 tax rebates was thus 11.3 percent.

There are several possible explanations for the larger rebate effect in 2008. First, the rebate checks were larger in 2008, and the larger rebate checks may have enabled more liquidity-constrained households to file for bankruptcy. Second, the rebate checks were more widely distributed: roughly 85 percent of households received rebate checks in 2008 versus 
57 percent in 2001 (Johnson et al., 2006; Parker et al., 2010). Third, the recession was more severe in 2008, which could have resulted in more liquidity-constrained households. All of these explanations would suggest a larger effect in 2008. Additionally, the BAPCPA dramatically changed the bankruptcy system in the intervening period (McIntyre et al., 2010), raising attorney fees and encouraging households to choose Chapter 13 rather than Chapter 7, though the expected effect of these legal changes on the 2008 results is less clear.

In contrast to the results for Chapter 7 filings, Table 3 suggests that the rebates had a smaller impact on Chapter 13 bankruptcies. Columns 3 and 4 present point estimates for Chapter 13 bankruptcies that are much smaller in magnitude than those for Chapter 7 . The estimates suggest a $2-5$ percent decrease in Chapter 13 filings, decreases that are marginally statistically significant in 2001 but not in 2008. The small decrease in Chapter 13 filings suggests that some households may have switched from Chapter 13 to Chapter 7 after the tax rebates. The increase in Chapter 7 filings, however, is much larger than the decrease in Chapter 13 filings, thus the filers who switch represent a small share of bankruptcies affected by the rebates.

This contrast between chapters is consistent with the existence of liquidity constraints. There are two relevant differences between Chapter 7 and Chapter 13. First, Chapter 7 filers have lower incomes and fewer assets than Chapter 13 filers. Second, households who file under Chapter 13 are charged higher legal fees, but are allowed to pay their attorneys after filing. ${ }^{16}$ Chapter 7 filers, on the other hand, must usually pay their attorneys in advance of filing. Both of these differences suggest that Chapter 7 filers are more likely to be liquidity constrained. ${ }^{17}$ And, indeed, Table 3 presents a much larger rebate effect for

\footnotetext{
${ }^{16}$ We constructed a random sample of 2001 and 2008 filings from the Central District of California. The average total cost of a Chapter 7 bankruptcy was $\$ 1,100$, while the average total cost of a Chapter 13 bankruptcy was $\$ 1,749$. The average attorney fees paid before filing were $\$ 995$ for Chapter 7 and $\$ 684$ for Chapter 13.

${ }^{17} \mathrm{An}$ additional reason for the contrast by chapter is that a large share of Chapter 13 filers turn to bankruptcy in order to halt a foreclosure (Mann and Porter, 2010). The timing of such bankruptcies is then determined by the foreclosure process rather than by rebates.
} 


\section{Chapter 7 bankruptcies.}

Finally, columns 5 and 6 of Table 3 present estimates for Chapter 7 and Chapter 13 filings combined. The point estimates are positive and statistically significant at conventional levels. They suggest that consumer bankruptcy filings overall increased by 2.3 percent in 2001 and by 6.8 percent in 2008 . Using equation (7), we can convert the estimated rebate effects into estimates of $s$, the share of bankruptcy filers who are constrained. The results suggest that $s=2.0$ percent in 2001 and $s=3.8$ percent in $2008 .{ }^{18}$

The remainder of this section discusses a simple falsification test. Figure 4 presents the results of this test. Each point represents estimates from specifications identical to those in column 2 of Table 3, but which are estimated for each year in our sample. We focus on Chapter 7 filings since our main effect is most pronounced for Chapter 7, and rely on the logbased specification in order to control for differences in filing rates across years. Tax rebates were not distributed by SSN group in years other than 2001 and 2008, but we construct indicator variables as if they were. Specifically, we construct placebo indicator variables consistent with the 2001 rebate distribution for 1998 through 2004. For 2005 through 2008, we construct placebo indicator variables consistent with the 2008 rebate distribution, and plot the sum of the paper check and direct deposit placebo effects. ${ }^{19}$

The figure presents no evidence of a strong rebate effect in any years other than those in which rebates were actually distributed. In all placebo tests, the confidence intervals do not exclude zero. A joint test of the hypothesis that all estimates except those for 2001 and 2008 are equal to zero fails to reject the null hypothesis with a $p$-value of 0.136 . In contrast, a joint test that the 2001 and 2008 estimates are jointly equal to zero leads to a $p$-value less than 0.001 .

\footnotetext{
${ }^{18}$ These estimates are based on assumptions that 57 percent of households received rebate checks in 2001, and 85 percent received them in 2008 (Johnson et al. (2006), Parker et al. (2010)).

${ }^{19}$ Note that the confidence intervals in Figure 4 are wider for estimates after 2004, because we plot the sum of the paper check and direct deposit effects.
} 


\subsection{Variation in the Rebate Effect Over Time}

This section describes how filing rates evolved over the weeks surrounding the rebates. To measure such patterns, we estimate an event-study specification. We modify the regression equation above to include indicator variables for 2-week intervals before and after the rebates. The 2 weeks before each group received its rebate is the omitted category.

Figure 5 presents the estimates from that regression when the outcome is the logarithm of Chapter 7 filings in 2001. The dotted lines plot 95-percent confidence intervals and the solid line plots the point estimates. The figure demonstrates that the bankruptcy rate increased by roughly 4 percent in the month after the rebates were distributed, and the treatment effect decreases monotonically after week $4 .^{20}$ Figure 6 presents analogous estimates for 2008 which show a similar pattern. ${ }^{21}$

Figure 7 and Figure 8 present the same event-study estimates for Chapter 13 bankruptcies in 2001 and 2008. Nearly all of the point estimates are statistically indistinguishable from zero, though the figures suggest a slight decline in Chapter 13 bankruptcies following the rebates, consistent with the results in Table 3.

As a whole, these figures suggest that the tax rebates led to an immediate, short-run increase in Chapter 7 bankruptcies. The increase in bankruptcies lasted for roughly four weeks after the rebates were distributed.

We interpret these results as providing evidence of the short-run, transitory effect of

\footnotetext{
${ }^{20}$ The results in Figure 5 suggest a modest, marginally significant increase in filing rates 3 and 4 weeks before the checks are sent in 2001. In contrast, Figure 6 suggests no discernable pre-trend in 2008. We cannot identify a cause for the pre-trend in Figure 5; potentially, households may have filed early, hoping to receive their rebates after their bankruptcy case was discharged. We view this as unlikely, however, as bankruptcies generally last for months, and judges were aware of the pending rebates. Nevertheless, it is possible that some households misperceived the laws regarding how the rebates were treated by the bankruptcy courts.

${ }^{21}$ The regression underlying Figure 6 also includes an indicator variable for whether the SSN group had received its direct deposit, so that these event study estimates report the dynamic effects of the rebates sent through the mail. A similar event study graph using the direct deposit dates is extremely imprecise due to the fact that there are only three direct deposite dates that are three weeks apart. This makes it very difficult to estimate the dynamic effects of the rebates sent via direct deposit. By contrast, the paper dates span roughly two months and are sent out at nine different dates.
} 
the rebates on consumer bankruptcies. We cannot identify households that did not receive a rebate, as all SSN groups eventually received rebates; therefore, we cannot estimate the long-run effects of the rebates. We strongly suspect, however, that the rebates had little permanent effect on bankruptcy filing rates. Instead, our estimates likely represent a shift in the timing of bankruptcies for households who were unable to file when they first wished to do so. We have two pieces of evidence in support of this interpretation. First, the pattern of event-study coefficients suggests the absence of a long-run effect; the estimated coefficients on the furthest lags are statistically and economically insignificant. Additionally, Appendix Table A1 reports results of an alternative specification that attempts to estimate the permanent effect of the rebates by comparing bankruptcy rates across months in different years. The test assumes that the permanent effect of the rebates can be estimated by comparing the total number of bankruptcies in the months during and after the rebates with the same months in other years, controlling for (within-year) seasonality in bankruptcy filings and controlling for long-run (across-year) trends in bankruptcy filings. ${ }^{22}$ Consistent with the event-study figures, Appendix Table A1 also suggests no permanent effect of the 2001 tax rebates. ${ }^{23}$

\subsection{Variation in the Rebate Effect by Local Characteristics}

This section tests how local characteristics are associated with the rebate effects. We record the ZIP code of residence for each bankruptcy filer in our database. We merge those ZIP codes to median household income and home ownership rate, as measured in the 2000 decennial census. This allows us to stratify our main specification by income. We also stratify filers by

\footnotetext{
${ }^{22} \mathrm{An}$ important weakness of this strategy is that it assumes that the timing of the rebate programs was exogenous. This is unlikely to be true; the rebate programs themselves were a political response to macroeconomic conditions that likely affected overall bankruptcy filings. Nevertheless, we are reassured by the similarity between the time-series results and the furthest lagged coefficients in the baseline model which suggest no permanent effects of the rebates.

${ }^{23}$ We only estimate the long-run effect of the 2001 tax rebate, because we have too little data after the 2008 rebates.
} 
a proxy for their access to credit. Following Mian and Sufi (2009), we merge each ZIP code to the share of its residents in 1996 that were categorized as subprime borrowers. ${ }^{24}$ Due to the rapid expansion of mortgage credit in subprime ZIP codes not matched by increases in household income, subprime ZIP codes are a plausible proxy for liquidity constraints (Mian and Sufi, 2009).

The theoretical model in Section 3 predicts that areas in which liquidity constraints are more prevalent should be associated with larger rebate effects. Thus, if income, home ownership, and sub-prime borrowing predict liquidity constraints, then these proxies should be associated with larger rebate effects. Liquidity, however, is determined by the difference between a household's income and expenditures, not just income, assets, or subprime status. Therefore, it is not clear a priori whether such proxies will have a discernible relationship with the rebate effect.

Table 4 presents estimates of equation (8) for Chapter 7 bankruptcies when the sample is stratified by terciles of these three variables. The first three columns present results for terciles of median income. The point estimates form different patterns in the two rebate years. In 2001, the point estimates suggest a U-shaped pattern; the second tercile of income is associated with the smallest rebate effect. In 2008, the first tercile of income is associated with the smallest total rebate effect. We emphasize, however, that none of these differences across the terciles is statistically significant at conventional levels.

The second set of columns of Table 4 present results when the sample is stratified by the likelihood of being a sub-prime borrower. The results also do not suggest a clear pattern. A Wald test of equality of the three coefficients in 2001 has a $p$-value of 0.11 , and in 2008 the associated $p$-value is 0.82 . We cannot reject the hypothesis that households from all terciles exhibited the same rebate effect. The last set of columns presents results when we stratify

\footnotetext{
${ }^{24}$ The variable captures the share of adults in the ZIP code whose FICO credit score was 660 or lower in 1996 (Mian and Sufi, 2009). We are extremely grateful to Atif Mian and Amir Sufi for assistance in acquiring these data.
} 
the sample by homeownership rate. Again, no clear pattern is present.

Overall, these results suggest a weak relationship between local characteristics and the rebate effect. The pattern of point estimates by tercile suggests that the rebate effect is not monotonically related to these proxies. Interestingly, Johnson et al. (2006) and Parker et al. (2010) find a non-monotonic effect for consumption. Both studies find that both lowand high-income households exhibit a higher sensitivity to tax rebates than middle-income households. The 2001 results in Table 4 exhibit the same pattern. Such a pattern suggests a complex relationship between liquidity and income, although we do not have enough precision to reach strong conclusions on this point.

\section{Analysis of Filers' Characteristics}

While the results above demonstrate that Chapter 7 bankruptcy rates increased after the tax rebates, a remaining question is which types of filers were responsible for that increase. In this section, we describe how the average characteristics of bankruptcy filers changed after the rebates. To do so, we collected legal documents for a random sample of consumer bankruptcies in ten districts. ${ }^{25}$ We randomly selected 250 Chapter 7 filings from each district in 2001 and 500 filings per district in 2008. ${ }^{26}$ For each filing, research assistants read the associated legal documents and recorded the financial characteristics of the household.

\subsection{Sample Statistics}

Households declaring bankruptcy must reveal many financial and demographic details to the court. Summary statistics for these details are presented in Table 5. The first set of

\footnotetext{
${ }^{25}$ We selected the districts based on whether the court judge was willing to grant us a waiver to download the files, and whether electronic records were available for both 2001 and 2008. The ten districts were: the Central District of California, the Northern and Southern Districts of Iowa, the Western District of Louisiana, the Southern District of New York, the Eastern and Western Districts of Oklahoma, the District of South Carolina, the Eastern District of Texas, and the Northern District of West Virginia.

${ }^{26}$ Twice as many filings were used in 2008 because the significant fraction of households receiving direct deposits instead of checks decreases the precision of our estimates.
} 
rows describe the demographics of filers. These average characteristics changed relatively little between 2001 and 2008. For instance, the percentage of primary filers who were female increased from 24 percent to 25 percent between the two years. A $t$-test fails to reject that the fraction of female filers remained constant (the associated $p$-value is 0.53 ). Filers were single in 34-35 percent of cases, separated or divorced in 16-20 percent of cases, and married in $46-49$ percent of cases. $^{27}$

The next set of rows in Table 5 describe the fees paid by filers. Fees generally increased from 2001 to 2008, largely driven by the BAPCPA. Filing fees are paid to the court at the time of filing. The BAPCPA standardized filing fees to $\$ 299$ for all Chapter 7 cases starting in 2005, increasing the average filing fee 50 percent from 2001 to $2008 .^{28}$ Average legal fees increased 70 percent from $\$ 746$ in 2001 to $\$ 1,265$ in 2008; that difference across years is statistically significant at the 1 -percent level. ${ }^{29}$

As shown in Table 5, the majority of legal fees are paid by the time of filing. Despite the increase in fees, the percentage of fees paid increased from 79 percent in 2001 to 86 percent in 2008. Instead of paying for formal legal representation, filers can elect to represent themselves in court and pay a smaller amount for legal advice and document preparation. The share of filers representing themselves declined from 3.4 percent to 1.8 percent. This last comparison suggests that the increased paperwork required by the BAPCPA made it more difficult for filers to forego formal legal representation.

The last set of numbers in Table 5 present statistics on the filers' finances. These statistics suggest three general patterns. First, filers were significantly wealthier in 2008 than in 2001. Average annual income increased from $\$ 23,784$ to $\$ 31,581$, total assets increased from $\$ 70,923$

\footnotetext{
${ }^{27}$ All filers were categorized into one of three marital-status categories according to the bankruptcy petition. If no marital information was provided, we categorized the filer as single. A $\chi^{2}$-test fails to reject that the shares of filers in the marital status categories changed between 2001 and 2008, p-value 0.18.

${ }^{28} \mathrm{~A}$ small number of filers receive waivers for the filing fees or arrange to pay them on installment. We find that fewer than 1 percent fail to pay the full amount by the time of filing.

${ }^{29}$ These numbers are roughly consistent with findings by the Government Accountability Office that attorney fees increased from $\$ 712$ in 2005 to $\$ 1,078$ in 2007 (GAO, 2008).
} 
to $\$ 112,259$, and total liabilities increase from $\$ 136,541$ to $\$ 181,823 .^{30}$ These patterns are surprising since a main goal of the BAPCPA was to discourage high-income households from filing for Chapter 7 bankruptcy. At the same time, the average liabilities-to-income ratio rose from 5.9 in 2001 to 6.6 in 2008, suggesting greater indebtedness. Consequently, it is not clear from these simple comparisons whether filers were more or less liquidity constrained in 2008.

Another pattern is that filers' liabilities dwarf their assets and income. In both years, the average filer bore liabilities roughly 6 times larger than their annual income and nearly twice as large as total assets. Finally, it is important to note that these financial variables are heavily skewed. For instance, mean liabilities in 2001 were $\$ 135,649$ while the median was less than half as large: $\$ 61,989$. As a result, we take the logarithm of these variables in the regression analysis reported in Appendix Table A2.

\subsection{Effect of the Rebates on the Characteristics of Bankruptcy Filers}

This section presents evidence of the effect of rebates on the characteristics of households filing for bankruptcy. Both our model and the estimates in section 4 suggest that the number of liquidity-constrained filers increases in the weeks after the rebates. This should lead to a change in the average characteristics of the filers.

We evaluate whether the rebates changed the characteristics of filers by presenting the distribution of several financial characteristics: (1) total liabilities, (2) debt-to-income ratio, and (3) annual income. The distributions allow us to compare those who filed before to those who filed after the rebates. We also report Kolmogorov-Smirnov (K-S) tests of the equality of these distributions. Additionally, Appendix Table A2 reports regression tables analogous to the figures presented in this section. ${ }^{31}$

\footnotetext{
${ }^{30}$ These differences across years are statistically significant at the 1-percent level

${ }^{31}$ The results in Appendix Table A2 are qualitatively similar to the figures reported in the main text, although the statistical precision is somewhat limited, especially when we include week fixed effects.
} 
Figure 9 and Figure 10 present empirical cumulative distribution functions for the total liabilities of filers in 2001 and 2008. In each figure, the solid line plots the distribution of total liabilities for those who filed after the rebates, while the dashed line plots the distribution for the filers who filed before the rebates. Both figures suggest that filers who filed after the rebates had higher total liabilities. In both figures, the associated K-S test rejects the null hypothesis that the distributions are identical.

Figure 11 and Figure 12 present a similar pattern for the ratio of total liabilities to income of each filer (debt-to-income ratio). The post-rebate filers have higher debt-to-income ratios. By contrast, we do not find consistent evidence that the distribution of income differs across the two groups of filers (Figure 13 and Figure 14).

Overall, the results above suggest that households filing for bankruptcy after the rebates are more likely to be liquidity constrained. Households filing after the rebates have larger liabilities and a higher debt-to-income ratio than households filing before the rebates. In contrast, they have roughly similar incomes.

\section{Discussion}

This section explores alternative explanations of our empirical results and discusses their implications for policy.

\subsection{Alternative Explanations}

We consider two alternative explanations for our findings. A first alternative explanation is that households timed their bankruptcy in order to keep their rebates from creditors or the court. This explanation, however, is unlikely. All pre-filing income and assets are subject to creditor action. Thus households trying to shield rebate income from creditors would have 
to file months before the rebates were sent. ${ }^{32}$ We find no evidence for such an effect. Were it to exist, this effect would bias our difference-in-difference estimates towards zero. Finally, as described in footnote 13 above, bankruptcy judges were aware of the rebates and were instructed to treat rebate income identically to other income.

A second alternative explanation is that households timed their bankruptcy so that they could consume the rebates before filing. This second explanation is also unlikely. The average "wild card" exemption under Chapter 7 is $\$ 7,073$ (Mahoney, 2010). It is unlikely that the rebates shifted a large share of households beyond that threshold. Moreover, if households were to file for bankruptcy only after consuming their rebates, then we would observe a decrease in bankruptcies before the rebates were distributed. The event study results above do not suggest such a decrease. Finally, this alternative explanation cannot readily account for the pattern across chapters or for the change in average liabilities before and after the rebates, as demonstrated in section 5 .

\subsection{Policy Implications}

Our empirical evidence suggests that legal fees force liquidity-constrained households to delay filing for bankruptcy. It is not obvious, however, whether lower fees would raise welfare. The effect of fees on social welfare depends on whether liquidity-constrained filers are those with the largest or the smallest utility gain from bankruptcy. If liquidity-constrained filers have the most to gain from bankruptcy, then entrance fees are likely to be socially inefficient. In this case, the bankruptcy system could otherwise rely on exemptions and the seizure of assets to deter bankruptcies. Conversely, if liquidity-constrained filers gain less from bankruptcy than other filers, then entrance fees may serve as an efficient mechanism to deter such bankruptcies. In this way, liquidity constraints transform entrance fees into

\footnotetext{
${ }^{32}$ Bankruptcy cases are open for many months. The filer can choose the filing date, but cannot choose the date when the case closes That date is determined by the resources of the court at the time of filing.
} 
ordeal mechanisms (Nichols and Zeckhauser, 1982).

The theoretical model in Section 3 suggests that constrained households suffer the greatest utility loss from fees and enjoy the greatest utility gain from being able to file for bankruptcy, thus supporting the argument made by Mann and Porter (2010) that a reduction in legal fees would be welfare enhancing. ${ }^{33}$ However, there are countervailing costs that must also be considered. High fees may prevent two forms of moral hazard. First, fees may inhibit households from borrowing excessively. Second, fees may deter bankruptcy, holding borrowing constant. Both of these forms of moral hazard must be balanced against the benefits of reducing fees. To the extent that liquidity-constrained filers impose larger moral hazard costs than the average filer, then filing fees may be effective in reducing moral hazard costs overall. An important task in future work will be quantifying the moral hazard costs associated with reducing entrance fees to bankruptcy.

\section{Conclusion}

We find that tax rebates cause a significant, short-run increase in consumer bankruptcies. This evidence is consistent with the hypothesis that legal fees force liquidity-constrained households to delay filing. These results highlight the importance of liquidity constraints in the optimal design of the consumer bankruptcy system.

An important area of future work is the consumption-smoothing benefits of bankruptcy. This is an important parameter in any comprehensive welfare analysis of the bankruptcy system. Such research will shed light on the extent to which rebate-induced bankruptcies provide effective economic stimulus. Our evidence suggests that tax rebates allow some households to avoid a delay in filing for bankruptcy. If these households substantially increase consumption following the discharge of their debts, then perhaps the timely discharge of

\footnotetext{
${ }^{33}$ Mann and Porter (2010) argue that congress can lower the amount of paperwork required for bankruptcy, which in turn, would lower legal fees. They propose an expedited form of bankruptcy for low-asset filers.
} 
household debt is an important component of economic stimulus policies.

Another area of future work is further investigation into the determinants of bankruptcy. A long-running debate centers over whether bankruptcies are primarily caused by unexpected negative shocks (Himmelstein et al., 2009; Fay et al., 2002). More recent work has emphasized the importance of myopic behavior (Hankins et al., 2011; Zhu, 2011). By contrast, our results suggest than an important (and overlooked) determinant of bankruptcy may be the ability of households simply to afford the fees.

Lastly, the concept that liquidity constraints affect the utilization (or take-up) of social insurance likely extends beyond consumer bankruptcy. Previous work has found that liquidity constraints are an important determinant of the behavioral response to unemployment insurance (Chetty, 2008), and we suspect that the decision to utilize unemployment insurance at all is also affected by liquidity constraints. Similarly, we suspect that the waiting periods for disability insurance interact with liquidity constraints in determining utilization. Thus, we believe a promising area for future research involves estimating the effect of liquidity constraints on the take-up of a broad range of social insurance programs. 


\section{References}

Agarwal, S., C. Liu, and N. Souleles (2007). The Reaction of Consumer Spending and Debt to Tax Rebates-Evidence from Consumer Credit Data. Journal of Political Economy 115(6), 986-1019.

Anderson, N. B. and J. K. Dokko (2011). Liquidity problems and early payment default among subprime mortgages. Working paper, Board of Governors of the Federal Reserve System.

Bertrand, M. and A. Morse (2009, May). What do high-interest borrowers do with their tax rebate? American Economic Review Papers and Proceedings.

Chetty, R. (2008). Moral hazard versus liquidity and optimal unemployment insurance. The Journal of Political Economy 116(2), 173-234.

Dynarski, S. (2003). Does Aid Matter? Measuring the Effect of Student Aid on College Attendance and Completion. The American Economic Review.

Evans, W. N. and T. J. Moore (2011, June). The Short-Term mortality consequences of income receipt. Journal of Public Economics.

Fay, S., E. Hurst, and M. White (2002, June). The household bankruptcy decision. American Economic Review 92(3), 706-718.

Filer, L. H. and J. D. Fisher (2005). The consumption effects associated with filing for personal bankruptcy. Southern Economic Journal 71(4), 837-854.

Gropp, R., J. K. Scholz, and M. J. White (1997). Personal bankruptcy and credit supply and demand. The Quarterly Journal of Economics 112(1), 217-251.

Gross, T. and J. Tobacman (2011, January). Income shocks and the demand for health care: Evidence from the 2008 stimulus payments. Unpublished.

Hankins, S., M. Hoekstra, and P. M. Skiba (2011, August). The ticket to easy street? the financial consequences of winning the lottery. Review of Economics and Statistics 93(3), 961-969.

Hansen, G. D. and A. İmrohoroğlu (1992). The role of unemployment insurance in an economy with liquidity constraints and moral hazard. The Journal of Political Economy $100(1), 118-142$.

Himmelstein, D., D. Thorne, E. Warren, and S. Woolhandler (2009, August). Medical bankrutpcy in the United States, 2007: Results of a national study. The American Journal of Medicine 122(8), 741-746.

Hsieh, C. (2003). Do consumers react to anticipated income changes? Evidence from the Alaska permanent fund. The American Economic Review 93(1), 397-405. 
Hurst, E. and A. Lusardi (2004). Liquidity constraints, household wealth, and entrepreneurship. Journal of Political Economy, 319-347.

Johnson, D., J. Parker, and N. Souleles (2006). Household expenditure and the income tax rebates of 2001. The American Economic Review 96(5), 1589-1610.

Lusardi, A., D. J. Schneider, and P. Tufano (2011, May). The state of macro. Working Paper 17072, National Bureau of Economic Research.

Mahoney, N. (2010, December). Bankruptcy as implicit health insurance. Mimeo, Stanford University.

Mann, R. and K. Porter (2010). Saving up for Bankruptcy. Georgetown Law Journal 98, 289-290.

McIntyre, F., D. Sullivan, and T. Layton (2010, January). Did BAPCPA Deter the Wealthy? The 2005 Bankruptcy Reform's Effect on Filings Across the Income and Asset Distribution. Unpublished.

Mian, A., K. Rao, and A. Sufi (2011, November). Household balance sheets, consumption, and the economic slump.

Mian, A. and A. Sufi (2009). The consequences of mortgage credit expansion: Evidence from the us mortgage default crisis. The Quarterly Journal of Economics 124(4), 1449-1496.

Nichols, A. L. and R. J. Zeckhauser (1982). Targeting transfers through restrictions on recipients. The American Economic Review 72(2), 372-377.

Parker, J. A., N. S. Souleles, D. S. Johnson, and R. McClelland (2010). Consumer spending and the economic stimulus payments of 2008. Unpublished paper, Northwestern University.

Shapiro, M. and J. Slemrod (2003). Did the 2001 Tax Rebate Stimulate Spending? Evidence from Taxpayer Surveys. Tax Policy and the Economy 17, 83-109.

Souleles, N. (1999). The Response of Household Consumption to Income Tax Refunds. The American Economic Review 89(4), 947-958.

Stavins, J. (2000, July/August). Credit card borrowing, deliquency, and personal bankruptcy. New England Economic Review, 15-30.

Stephens, M. (2003). "3 $3^{\text {rd }}$ of the Month": Do Social Security Recipients Smooth Consumption Between Checks? The American Economic Review 93(1), 406-422.

GAO (2008, June). Bankruptcy reform: Dollar costs associated with the bankruptcy abuse prevention and consumer protection act of 2005. Report to Congressional Requesters GAO-08-697, United States Government Accountability Office.

Wang, H.-J. and M. White (2000, January). An optimal personal bankruptcy procedure and proposed reforms. Journal of Legal Studies 29, 255-286. 
Zhu, N. (2011). Household consumption and personal bankruptcy. Journal of Legal Studies $40(1), 1-37$.

Zywicki, T. J. (2005). An economic analysis of the consumer bankruptcy crisis. Northwestern University Law Review 99(4), 1463-1542. 


\section{Figure 1: Bankruptcy Districts in Sample}

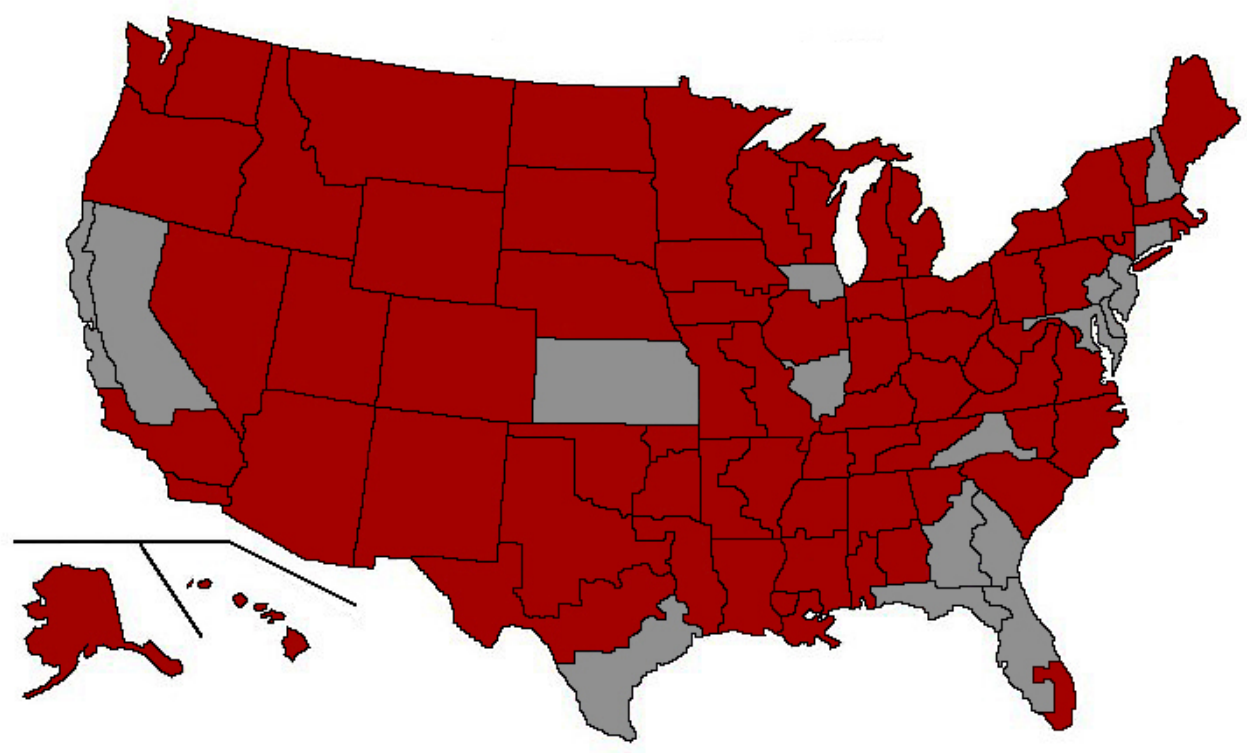

Figure 2. Randomization Test

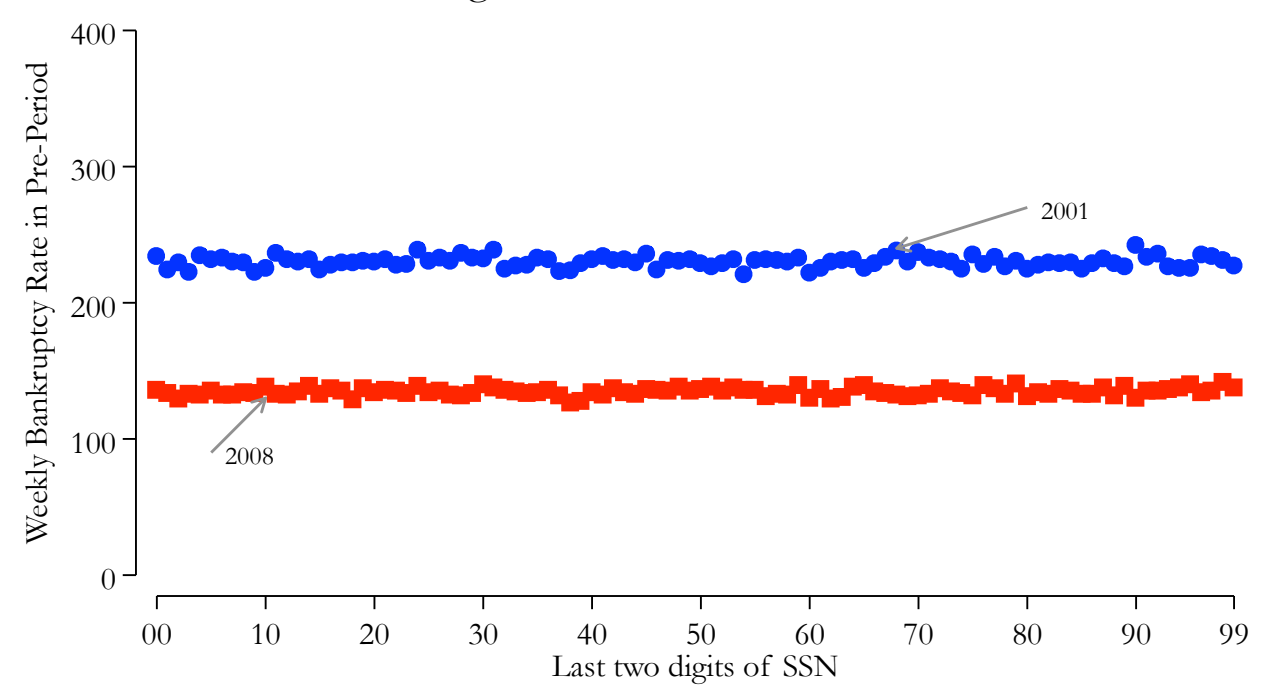

This graph plots bankruptcies in March, April, and May of 2001 and in

January, February, and March of 2008. The distribution of the 2001 tax rebates

began in July, and the distribution of the 2008 tax rebates began in May. An

F-test fails to reject the hypothesis that weekly bankruptcy rates are

equal across groups with p-value 0.726 in 2001 and 0.864 in 2008 . 
Figure 3. Types of Households

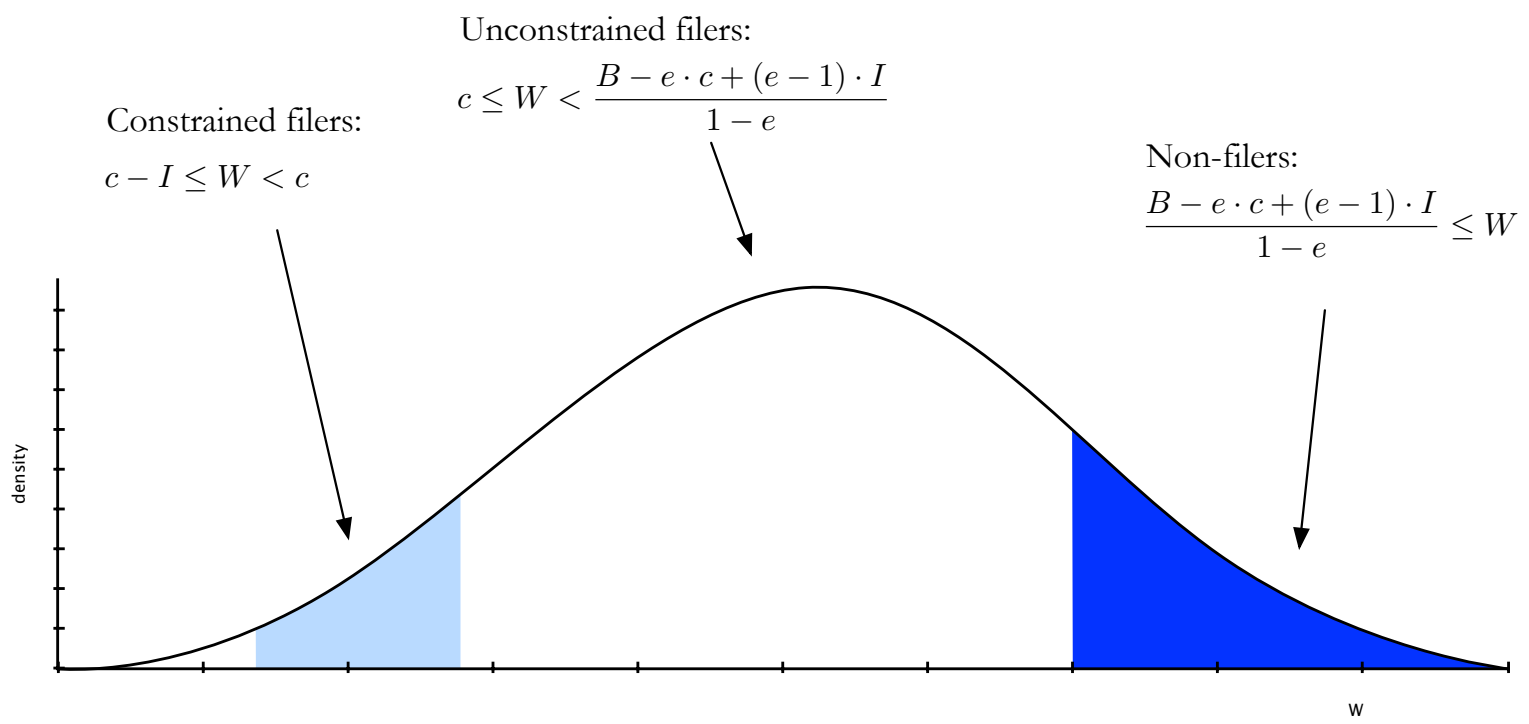

Figure 4. Chapter 7 Rebate Effect by Year

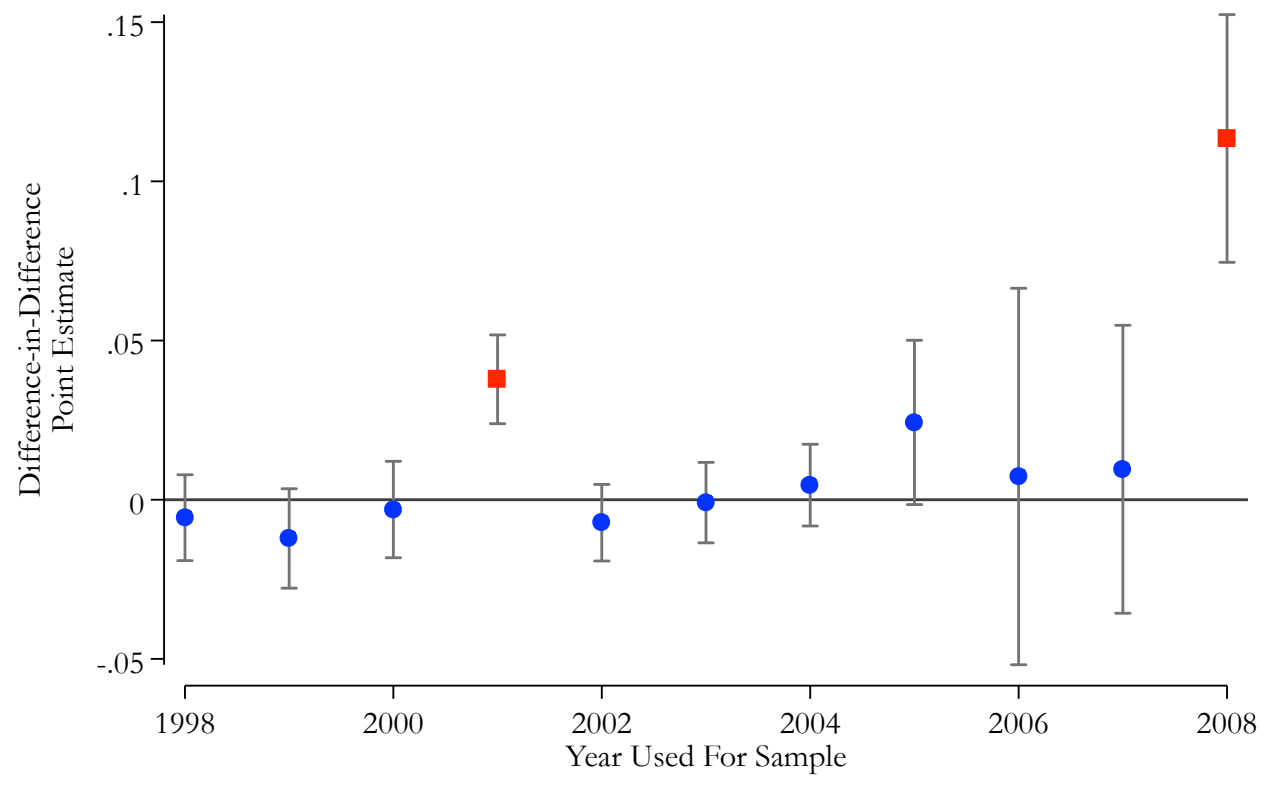

Note: Tax rebates were sent in 2001 and 2008. 
Figure 5. Event Study Point Estimates, 2001 Dependent Variable: Log of Chapter 7 Filings

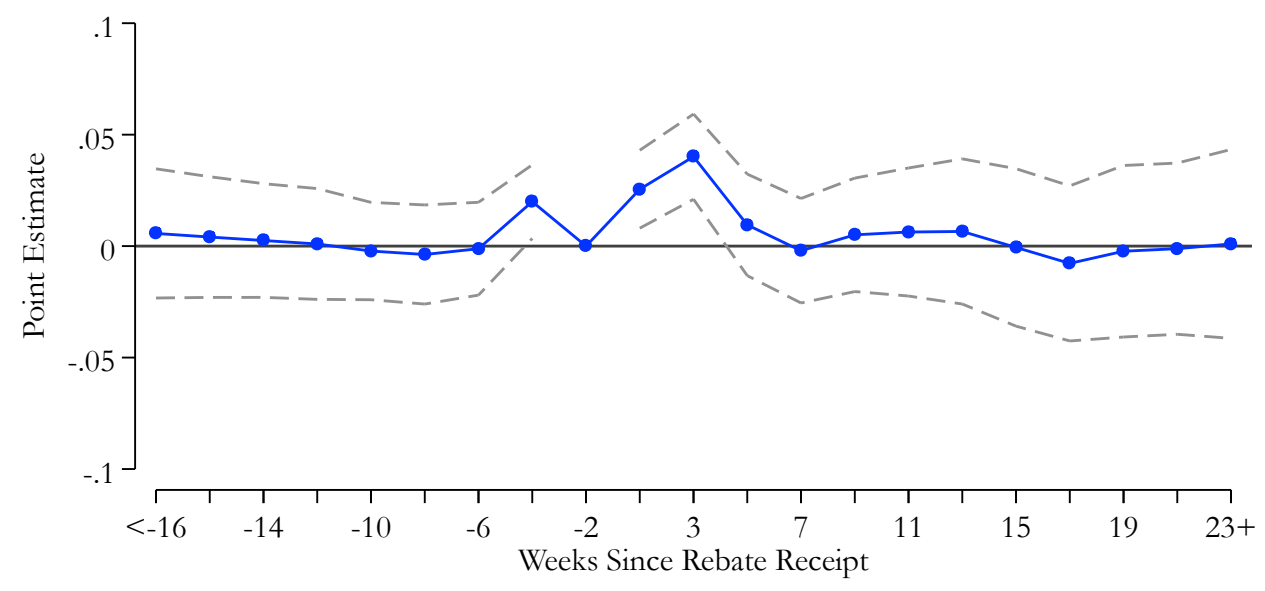

The figure presents point estimates from a regression of log counts of bankruptcies on indicators for two-week intervals. The dotted lines represent $95 \%$ confidence intervals that are robust to autocorrelation between observations from the same SSN group. The sample consists of bankruptcies by SSN group and week, covering 30 weeks before and 40 weeks after groups were sent their tax rebate checks. SSN-group fixed effects and week fixed effects not shown. The omitted time period is 1 and 2 weeks before rebate checks were sent.

Figure 6. Event Study Point Estimates, 2008 Dependent Variable: Log of Chapter 7 Filings

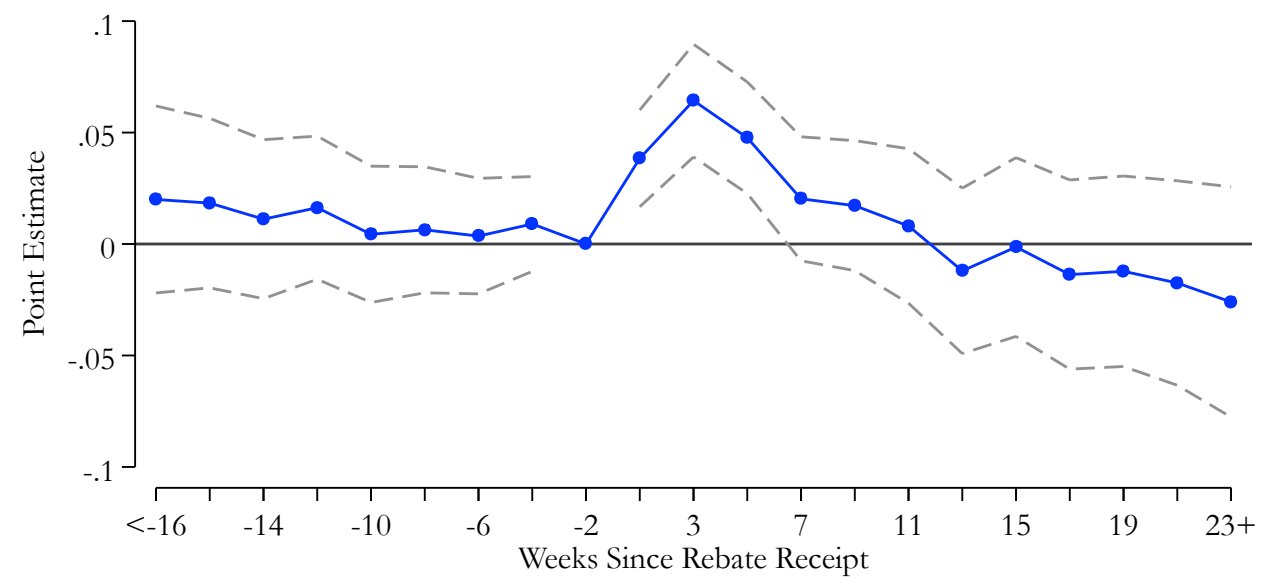

The figure presents point estimates from a regression of log counts of bankruptcies on indicators for two-week intervals. The dotted lines represent $95 \%$ confidence intervals that are robust to autocorrelation between observations from the same SSN group. The sample consists of bankruptcies by SSN group and week, covering 30 weeks before and 40 weeks after groups were sent their tax rebate checks. SSN-group fixed effects and week fixed effects not shown. The omitted time period is 1 and 2 weeks before rebate checks were sent. 
Figure 7. Event Study Point Estimates, 2001 Dependent Variable: Log of Chapter 13 Filings

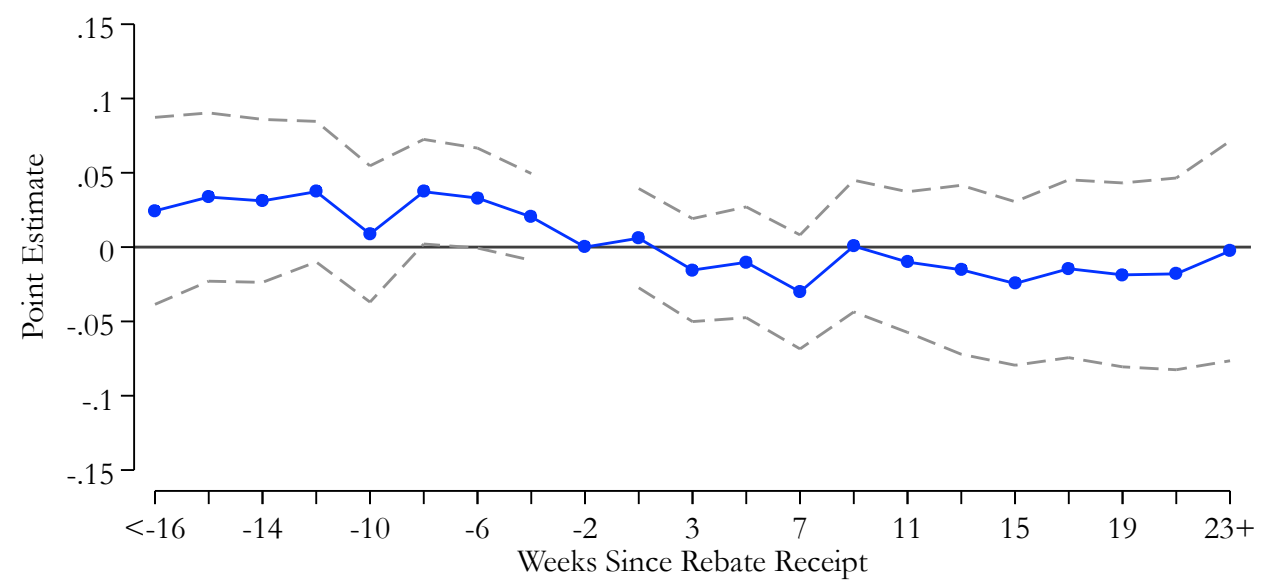

The figure presents point estimates from a regression of log counts of bankruptcies on indicators for two-week intervals. The dotted lines represent $95 \%$ confidence intervals that are robust to autocorrelation between observations from the same SSN group. The sample consists of bankruptcies by SSN group and week, covering 30 weeks before and 40 weeks after groups were sent their tax rebate checks. SSN-group fixed effects and week fixed effects not shown. The omitted time period is 1 and 2 weeks before rebate checks were sent.

Figure 8. Event Study Point Estimates, 2008 Dependent Variable: Log of Chapter 13 Filings

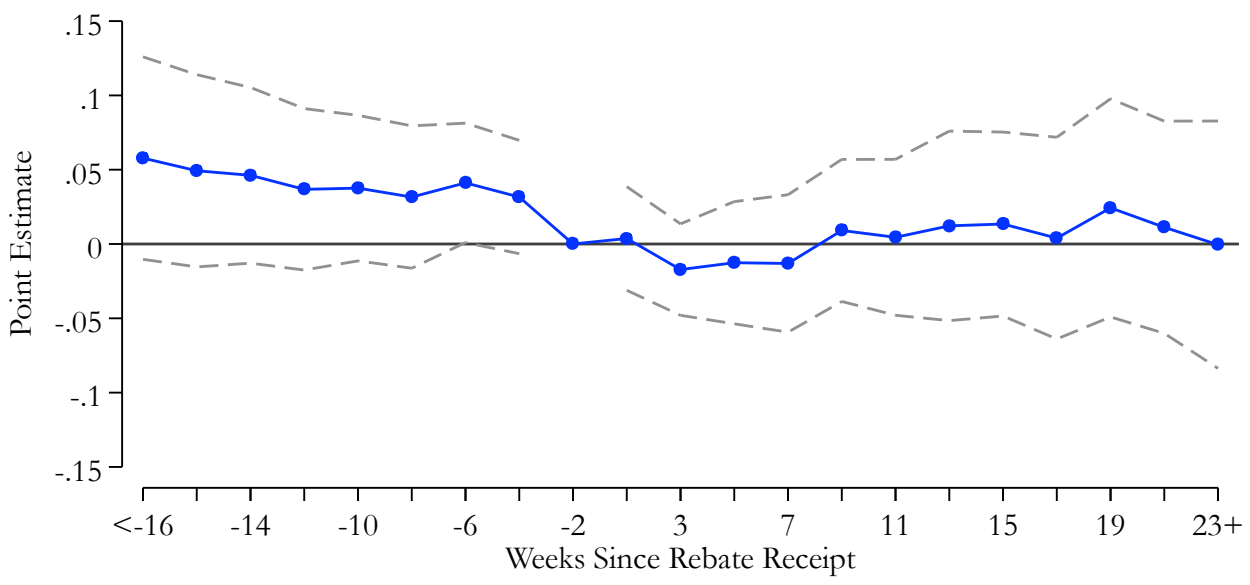

The figure presents point estimates from a regression of log counts of bankruptcies on indicators for two-week intervals. The dotted lines represent $95 \%$ confidence intervals that are robust to autocorrelation between observations from the same SSN group. The sample consists of bankruptcies by SSN group and week, covering 30 weeks before and 40 weeks after groups were sent their tax rebate checks. SSN-group fixed effects and week fixed effects not shown. The omitted time period is 1 and 2 weeks before rebate checks were sent. 
Figure 9: Filers' Liabilities Before and After the Rebates, 2001

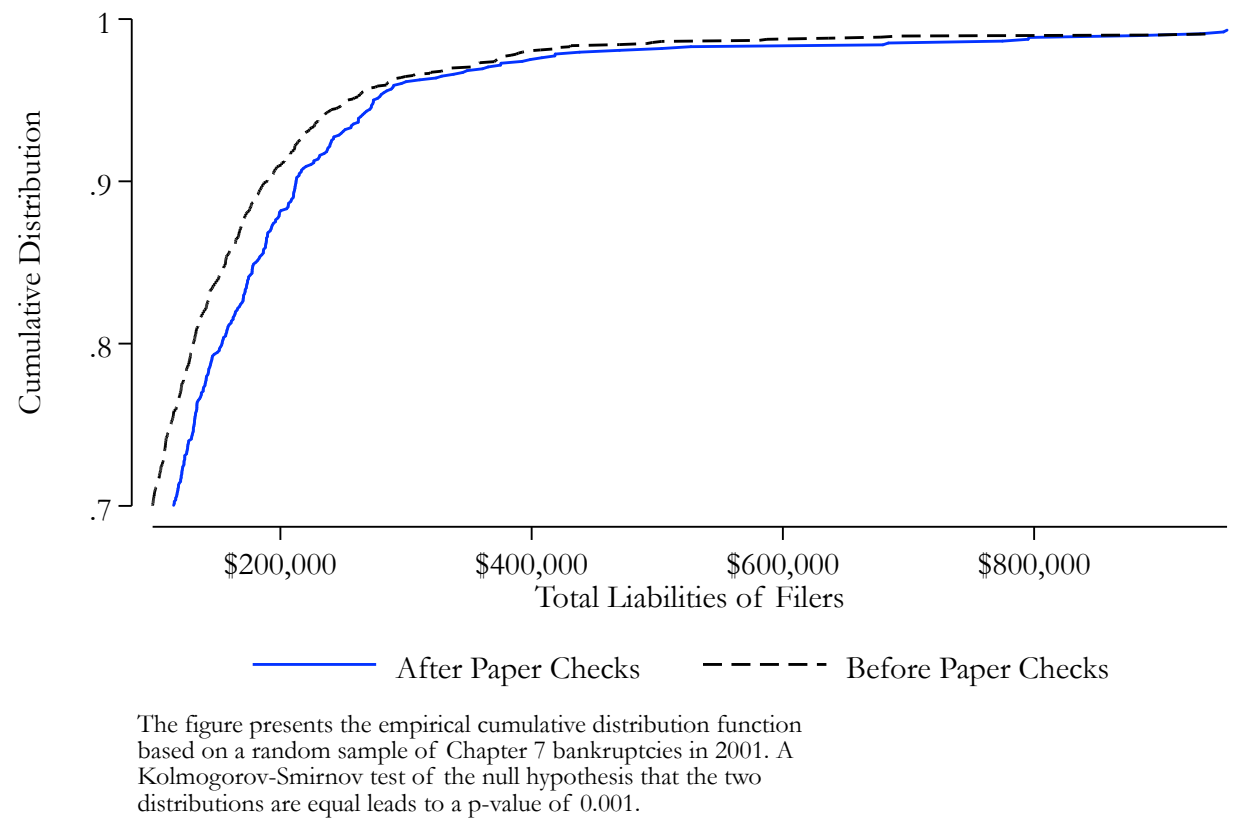

Figure 10: Filers' Liabilities Before and After the Rebates, 2008

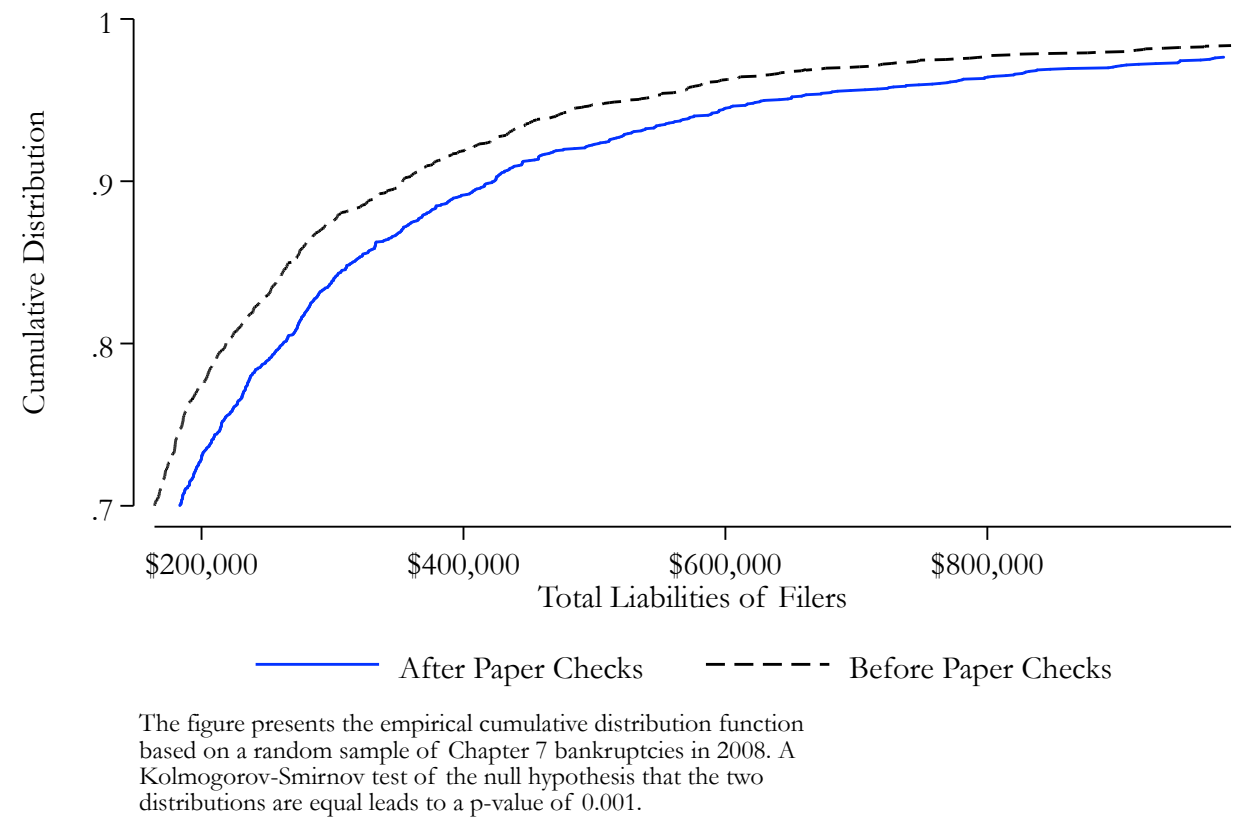




\section{Figure 11: Filers' Liabilities-to-Income Ratio \\ Before and After the Rebates, 2001}

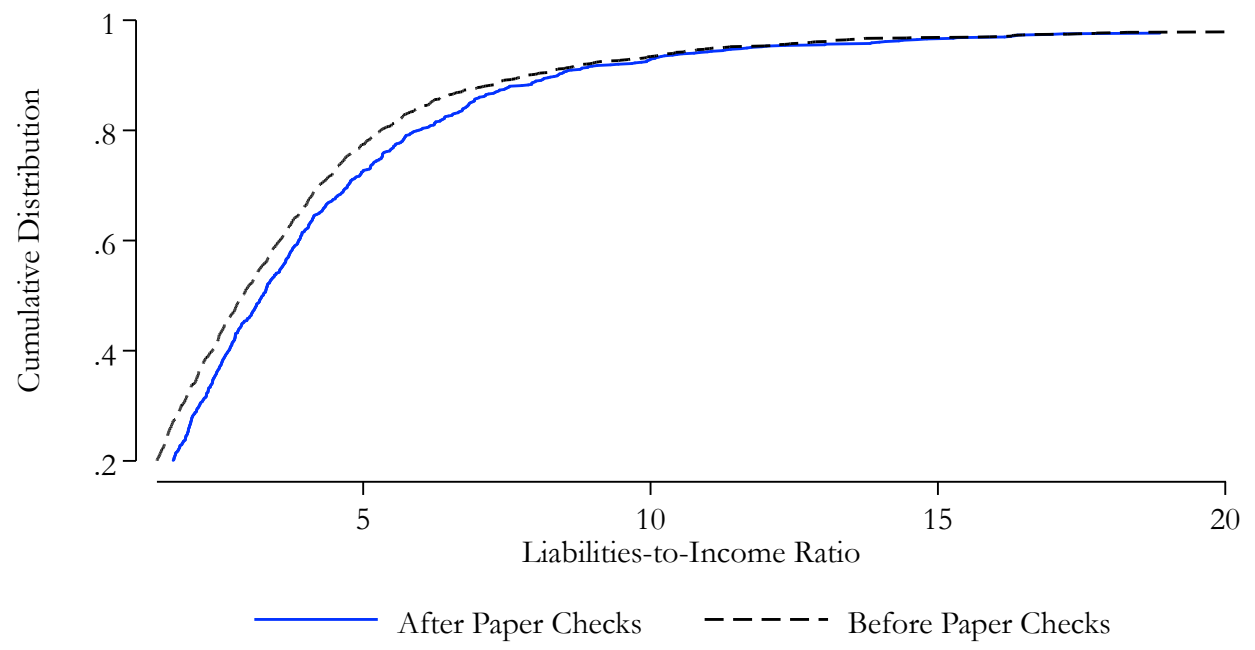

The figure presents the empirical cumulative distribution function

based on a random sample of Chapter 7 bankruptcies in 2001. A

Kolmogorov-Smirnov test of the null hypothesis that the two

distributions are equal leads to a p-value of 0.004 .

Figure 12: Filers' Liabilities-to-Income Ratio

Before and After the Rebates, 2008

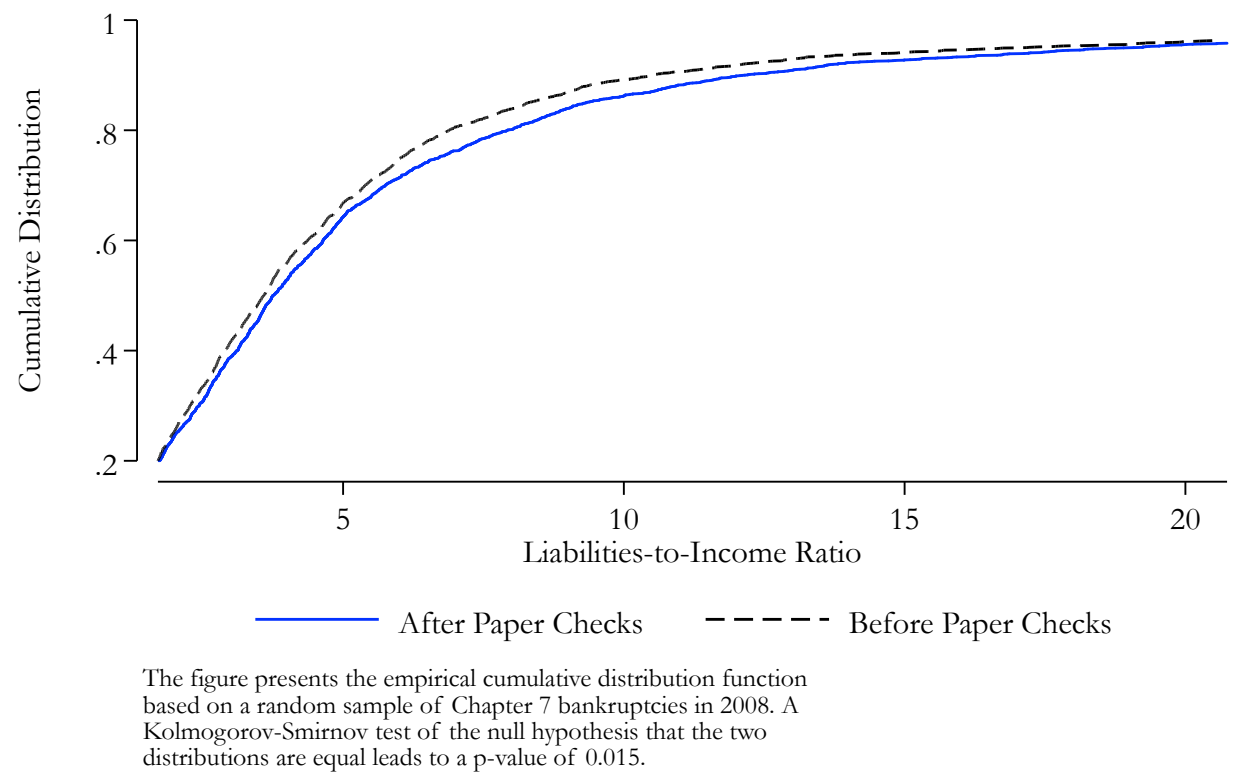


Figure 13: Filers' Income Before and After the Rebates, 2001

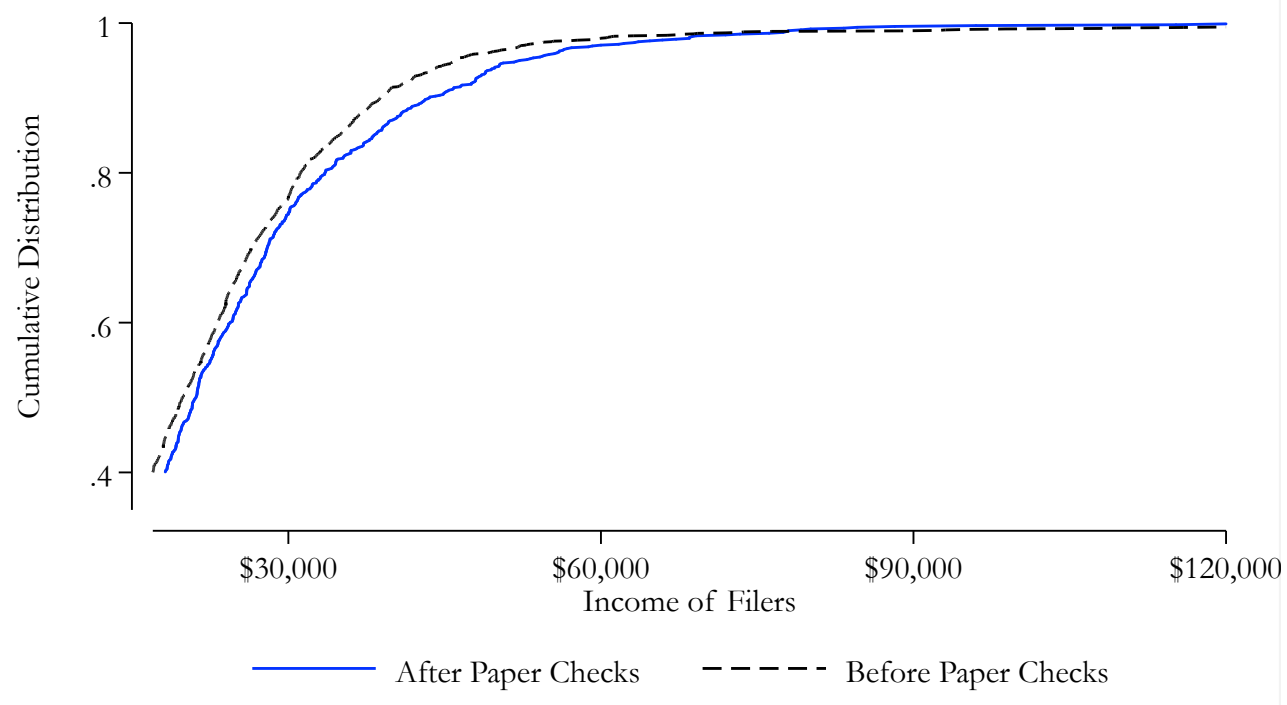

The figure presents the empirical cumulative distribution function

based on a random sample of Chapter 7 bankruptcies in 2001. A

Kolmogorov-Smirnov test of the null hypothesis that the two

distributions are equal leads to a p-value of 0.097 .

Figure 14: Filers' Income Before and After the Rebates, 2008

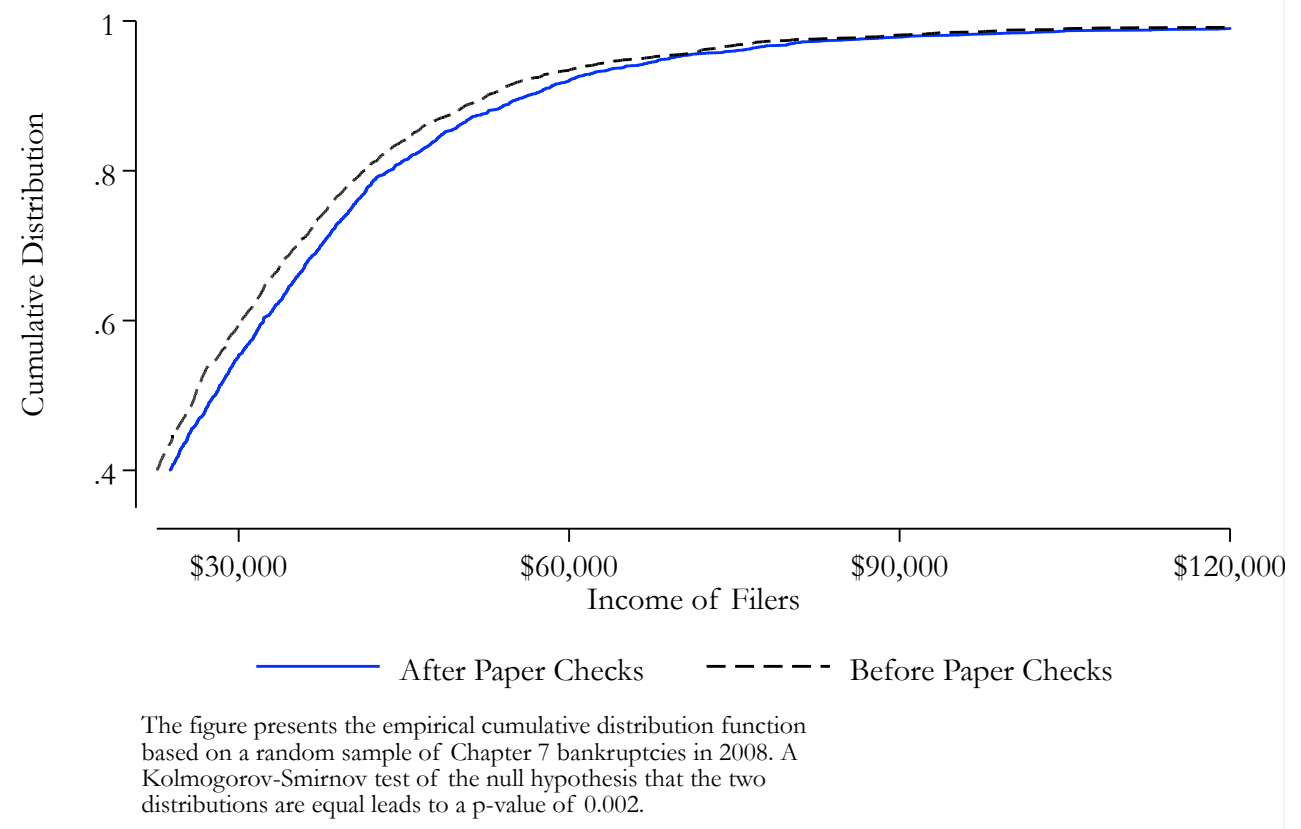


Table 1: Sample Coverage

\begin{tabular}{|c|c|c|c|c|}
\hline & $\begin{array}{r}\text { Districts } \\
\text { in sample }\end{array}$ & $\begin{array}{r}\text { Districts } \\
\text { not in sample }\end{array}$ & $\begin{array}{r}\text { All } \\
\text { Districts } \\
\end{array}$ & $\begin{array}{l}\text { Coverage } \\
\text { in our sample }\end{array}$ \\
\hline & \multicolumn{4}{|c|}{ A. 2001 Sample } \\
\hline Consumer bankruptcies & 259,961 & 90,020 & 349,981 & $74 \%$ \\
\hline Chapter 7 & 186,229 & 58,484 & 244,713 & $76 \%$ \\
\hline Chapter 13 & 73,613 & 31,487 & 105,100 & $70 \%$ \\
\hline Population & $201,904,852$ & $75,112,770$ & $277,017,622$ & $73 \%$ \\
\hline Median Family Income & 40,990 & 48,139 & 42,497 & \\
\hline Unemployment Rate & $4.70 \%$ & $4.86 \%$ & $4.75 \%$ & \\
\hline Percent College & $23.9 \%$ & $27.4 \%$ & $25.5 \%$ & \\
\hline \multirow[t]{2}{*}{ Median Housing Value } & 117,012 & 151,670 & 124,076 & \\
\hline & \multicolumn{4}{|c|}{ B. 2008 Sample } \\
\hline Consumer bankruptcies & 272,182 & 90,559 & 362,741 & $75 \%$ \\
\hline Chapter 7 & 183,788 & 58,740 & 242,528 & $76 \%$ \\
\hline Chapter 13 & 88,208 & 31,706 & 119,914 & $74 \%$ \\
\hline Total population & $222,045,717$ & $54,971,905$ & $304,059,728$ & $73 \%$ \\
\hline Median Family Income & 50,169 & 61,021 & 50,861 & \\
\hline Unemployment Rate & $5.69 \%$ & $6.06 \%$ & $5.79 \%$ & \\
\hline Percent College & $27.0 \%$ & $29.4 \%$ & $27.7 \%$ & \\
\hline Median Housing Value & 210,302 & 306,000 & 214,900 & \\
\hline
\end{tabular}

Note: This table describes the characteristics of the bankruptcy districts in our sample. See text for details. 
Table 2. Dates When Rebate Checks Were Sent

\begin{tabular}{|c|c|c|c|c|c|}
\hline $\begin{array}{c}\text { Last } 2 \text { Digits } \\
\text { of SSN's }\end{array}$ & $\begin{array}{r}2001 \text { Rebate } \\
\text { Check Sent }\end{array}$ & $\begin{array}{c}\text { Last } 2 \text { Digits } \\
\text { of SSN's }\end{array}$ & $\begin{array}{r}2008 \text { Stimulus } \\
\text { Check Sent } \\
\end{array}$ & $\begin{array}{c}\text { Last } 2 \text { Digits } \\
\text { of SSN's }\end{array}$ & $\begin{array}{l}2008 \text { Stimulus } \\
\text { Deposit Made }\end{array}$ \\
\hline $00-09$ & July 20 & $00-09$ & May 16 & $00-20$ & May 2 \\
\hline $10-19$ & July 27 & $10-18$ & May 23 & $21-75$ & May 9 \\
\hline $20-29$ & August 3 & $19-25$ & May 30 & $76-99$ & May 16 \\
\hline $30-39$ & August 10 & $26-38$ & June 6 & & \\
\hline $40-49$ & August 17 & $39-51$ & June 13 & & \\
\hline $50-59$ & August 24 & $52-63$ & June 20 & & \\
\hline $60-69$ & August 31 & $64-75$ & June 27 & & \\
\hline $70-79$ & September 7 & $76-87$ & July 4 & & \\
\hline $80-89$ & September 14 & $88-99$ & July 11 & & \\
\hline $90-99$ & September 21 & 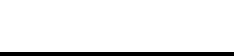 & & & \\
\hline
\end{tabular}


Table 3: The Effect of Rebate Checks on Bankruptcies

Dependent Variable: Level or logarithm of total bankruptcy filings

per SSN group per week

\begin{tabular}{|c|c|c|c|c|c|c|}
\hline & (1) & $(2)$ & (3) & (4) & (5) & $(6)$ \\
\hline & \multicolumn{2}{|c|}{ Chapter 7} & \multicolumn{2}{|c|}{ Chapter 13} & \multicolumn{2}{|c|}{ All } \\
\hline & Levels & Logs & Levels & Logs & Levels & Logs \\
\hline & \multicolumn{6}{|c|}{ A. 2001 Tax Rebates } \\
\hline After & 5.640 & 0.038 & -1.160 & -0.024 & 4.480 & 0.023 \\
\hline Check & $(1.024)$ & $(0.007)$ & $(0.564)$ & $(0.011)$ & $(1.116)$ & $(0.006)$ \\
\hline Sent & {$[0.000]$} & {$[0.000]$} & {$[0.042]$} & {$[0.030]$} & {$[0.000]$} & {$[0.000]$} \\
\hline \multirow[t]{2}{*}{$\mathrm{R}^{2}$} & 0.776 & 0.787 & 0.473 & 0.473 & 0.771 & 0.791 \\
\hline & \multicolumn{6}{|c|}{ B. 2008 Tax Rebates } \\
\hline After & 5.445 & 0.051 & -0.471 & -0.011 & 4.974 & 0.033 \\
\hline Check & $(0.948)$ & $(0.009)$ & $(0.535)$ & $(0.012)$ & $(1.039)$ & $(0.007)$ \\
\hline Sent & {$[0.000]$} & {$[0.000]$} & {$[0.380]$} & {$[0.361]$} & {$[0.000]$} & {$[0.000]$} \\
\hline After & 6.388 & 0.062 & -1.538 & -0.037 & 4.850 & 0.035 \\
\hline Direct & $(1.695)$ & $(0.017)$ & $(0.889)$ & $(0.023)$ & $(1.817)$ & $(0.013)$ \\
\hline Deposit & {$[0.000]$} & {$[0.000]$} & [0.087] & [0.105] & [0.009] & [0.009] \\
\hline Total & 11.834 & 0.113 & -2.009 & -0.048 & 9.824 & 0.068 \\
\hline \multirow[t]{2}{*}{ Effect } & (1.973) & $(0.020)$ & $(1.092)$ & $(0.027)$ & $(2.161)$ & $(0.016)$ \\
\hline & {$[0.000]$} & {$[0.000]$} & [0.069] & [0.079] & [0.000] & {$[0.000]$} \\
\hline $\mathrm{R}^{2}$ & 0.865 & 0.860 & 0.559 & 0.568 & 0.868 & 0.866 \\
\hline
\end{tabular}

Note: $\mathrm{N}=7,100$. The sample consists of counts of bankruptcies by two-digit SSN group and week, covering 30 weeks before and 40 weeks after groups were sent their tax rebate checks. The standard errors in parentheses are robust to autocorrelation between observations from the same SSN group. The associated p-values are in brackets. SSN-group fixed effects and week fixed effects not shown. 
Table 4: The Effect of Rebate Checks by Local Characteristics

Dependent Variable: logarithm of chapter 7 bankruptcy filings per SSN group per week

\begin{tabular}{|c|c|c|c|c|c|c|c|c|c|}
\hline & $(1 \mathrm{a})$ & $(1 \mathrm{~b})$ & $(1 \mathrm{c})$ & $(2 a)$ & $(2 \mathrm{~b})$ & $(2 \mathrm{c})$ & $(3 a)$ & $(3 \mathrm{~b})$ & $(3 c)$ \\
\hline & \multicolumn{3}{|c|}{$\begin{array}{c}\text { Bankruptcies stratified by median } \\
\text { family income in } \\
\text { zip code }\end{array}$} & \multicolumn{3}{|c|}{$\begin{array}{c}\text { Bankruptcies stratified by } \\
\text { share of zip code residents who are } \\
\text { sub-prime borrowers }\end{array}$} & \multicolumn{3}{|c|}{$\begin{array}{l}\text { Bankruptcies stratified by } \\
\text { homeownership rate in zip code }\end{array}$} \\
\hline & $\begin{array}{r}\text { First } \\
\text { Tercile }\end{array}$ & $\begin{array}{l}\text { Second } \\
\text { Tercile }\end{array}$ & $\begin{array}{l}\text { Third } \\
\text { Tercile }\end{array}$ & $\begin{array}{l}\text { First } \\
\text { Tercile }\end{array}$ & $\begin{array}{l}\text { Second } \\
\text { Tercile }\end{array}$ & $\begin{array}{l}\text { Third } \\
\text { Tercile }\end{array}$ & $\begin{array}{l}\text { First } \\
\text { Tercile }\end{array}$ & $\begin{array}{l}\text { Second } \\
\text { Tercile }\end{array}$ & $\begin{array}{l}\text { Third } \\
\text { Tercile }\end{array}$ \\
\hline & \multicolumn{9}{|c|}{ A. 2001 Tax Rebates } \\
\hline After & 0.048 & 0.026 & 0.045 & 0.044 & 0.052 & 0.019 & 0.029 & 0.028 & 0.057 \\
\hline Check & $(0.011)$ & $(0.012)$ & $(0.015)$ & $(0.013)$ & $(0.011)$ & $(0.011)$ & $(0.012)$ & $(0.013)$ & $(0.012)$ \\
\hline Sent & {$[0.000]$} & {$[0.032]$} & {$[0.003]$} & {$[0.002]$} & {$[0.000]$} & {$[0.105]$} & {$[0.015]$} & {$[0.028]$} & {$[0.000]$} \\
\hline \multirow[t]{2}{*}{$\mathrm{R}^{2}$} & 0.585 & 0.599 & 0.465 & 0.512 & 0.595 & 0.555 & 0.555 & 0.581 & 0.522 \\
\hline & \multicolumn{9}{|c|}{ B. 2008 Tax Rebates } \\
\hline After & 0.053 & 0.054 & 0.050 & 0.049 & 0.058 & 0.046 & 0.045 & 0.048 & 0.059 \\
\hline Check & $(0.016)$ & $(0.015)$ & $(0.014)$ & $(0.016)$ & $(0.014)$ & $(0.017)$ & $(0.019)$ & $(0.015)$ & $(0.013)$ \\
\hline Sent & {$[0.002]$} & {$[0.000]$} & {$[0.000]$} & {$[0.003]$} & {$[0.000]$} & {$[0.009]$} & {$[0.020]$} & {$[0.002]$} & {$[0.000]$} \\
\hline After & 0.005 & 0.085 & 0.076 & 0.075 & 0.058 & 0.047 & 0.022 & 0.066 & 0.084 \\
\hline Direct & $(0.030)$ & $(0.030)$ & $(0.030)$ & $(0.030)$ & $(0.030)$ & $(0.035)$ & $(0.035)$ & $(0.033)$ & $(0.027)$ \\
\hline Deposit & {$[0.863]$} & {$[0.006]$} & {$[0.012]$} & {$[0.016]$} & {$[0.057]$} & {$[0.176]$} & {$[0.540]$} & {$[0.049]$} & {$[0.002]$} \\
\hline Total & 0.058 & 0.139 & 0.126 & 0.075 & 0.058 & 0.047 & 0.066 & 0.114 & 0.143 \\
\hline \multirow[t]{2}{*}{ Effect } & $(0.035)$ & $(0.034)$ & $(0.035)$ & $(0.030)$ & $(0.030)$ & $(0.035)$ & $(0.041)$ & $(0.038)$ & $(0.032)$ \\
\hline & {$[0.098]$} & {$[0.000]$} & {$[0.001]$} & {$[0.016]$} & {$[0.057]$} & {$[0.176]$} & {$[0.107]$} & [0.004] & [0.000] \\
\hline $\mathrm{R}^{2}$ & 0.616 & 0.702 & 0.658 & 0.648 & 0.702 & 0.632 & 0.613 & 0.669 & 0.669 \\
\hline
\end{tabular}

Note: $\mathrm{N}=7,100$. The sample consists of counts of bankruptcies by two-digit SSN group and week, covering 30 weeks before and 40 weeks after groups were sent their tax rebate checks. The standard errors in parentheses are robust to autocorrelation between observations from the same SSN group. The associated p-values are in brackets. SSN group fixed effects and week fixed effects not shown. 
Table 5: Summary Statistics for Filings from Ten Districts

\begin{tabular}{|c|c|c|c|c|c|c|}
\hline & Mean & Median & Std. Dev. & Mean & Median & Std. Dev. \\
\hline & & A. 2001 & & & B. 2008 & \\
\hline \multicolumn{7}{|l|}{$\underline{\text { Household Composition }}$} \\
\hline Female & $24 \%$ & & & $25 \%$ & & \\
\hline Single & $35 \%$ & & & $34 \%$ & & \\
\hline Separated or Divorced & $16 \%$ & & & $20 \%$ & & \\
\hline Married & $49 \%$ & & & $46 \%$ & & \\
\hline Number of children & 1.04 & 1 & 1.20 & 0.92 & 0 & 1.20 \\
\hline \multicolumn{7}{|l|}{ Fees } \\
\hline Filing fee & $\$ 199$ & $\$ 200$ & $\$ 15$ & $\$ 299$ & $\$ 299$ & $\$ 0$ \\
\hline Legal fee promised & $\$ 746$ & $\$ 700$ & $\$ 397$ & $\$ 1,265$ & $\$ 1,099$ & $\$ 654$ \\
\hline Legal fee $\%$ paid & $79 \%$ & $100 \%$ & $30 \%$ & $86 \%$ & $100 \%$ & $30 \%$ \\
\hline Self-representation & $3.4 \%$ & & & $1.8 \%$ & & \\
\hline \multicolumn{7}{|l|}{ Financial Characteristics } \\
\hline Annual income & $\$ 23,784$ & $\$ 20,403$ & $\$ 24,656$ & $\$ 31,581$ & $\$ 26,738$ & $\$ 26,369$ \\
\hline Annual expenses & $\$ 28,212$ & $\$ 23,712$ & $\$ 54,312$ & $\$ 35,868$ & $\$ 30,480$ & $\$ 28,668$ \\
\hline Total assets & $\$ 70,923$ & $\$ 31,883$ & $\$ 310,346$ & $\$ 112,259$ & $\$ 55,074$ & $\$ 440,894$ \\
\hline Total liabilities & $\$ 136,541$ & $\$ 62,896$ & $\$ 1,021,721$ & $\$ 181,823$ & $\$ 101,943$ & $\$ 392,214$ \\
\hline$\%$ of liabilities secured & $42 \%$ & $46 \%$ & $30 \%$ & $42 \%$ & $44 \%$ & $30 \%$ \\
\hline Liabilities-to-income ratio & 5.9 & 3.05 & 34.5 & 6.6 & 3.7 & 20.5 \\
\hline
\end{tabular}

Note: This table presents statistics for a sample of chapter 7 bankruptcies from 10 bankruptcy districts.

The sample consists of 2,132 bankruptcies in 2001 and 4,355 bankruptcies in 2008. See text for details on how the sample was constructed. 
Appendix Table A1: The Long-Run Effect of the 2001 Rebates

Dependent Variable: Log of chapter 7 bankruptcies by month

\begin{tabular}{lrrrr}
\hline & $(1)$ & $(2)$ & $(3)$ & $(4)$ \\
\hline & & & & \\
After 2001 & 0.000 & -0.004 & -0.017 & 0.006 \\
Tax Rebates & $(0.039)$ & $(0.050)$ & $(0.050)$ & $(0.030)$ \\
& {$[1.000]$} & {$[0.937]$} & {$[0.743]$} & {$[0.844]$} \\
$\mathrm{R}^{2}$ & & & & \\
$\mathrm{~N}$ & 0.660 & 0.661 & 0.666 & 0.908 \\
& 84 & 84 & 84 & 84 \\
Cubic polynomial in time & $\mathrm{X}$ & & & \\
Quartic polynomial in time & & $\mathrm{X}$ & & \\
Quintic polynomial in time & & & $\mathrm{X}$ & $\mathrm{X}$ \\
Month fixed effects & & & & $\mathrm{X}$ \\
\hline
\end{tabular}

Note: This table reports results from a regression of log bankruptcies on a dummy for the period between June, 2001 and March, 2002 (inclusive). This captures two months before the 2001 tax rebate and six months afterwards. The sample includes the months between January, 1998 and December, 2004 (inclusive), and the unit of observation is month-year. The time polynomials are functions of the number of months since the start of the sample period, and are intended to capture long-run trends in bankruptcy filings. Heteroskedasticity-robust standard errors are in parentheses, and pvalues are in brackets. 
Appendix Table A2: The Effect of the Tax Rebates on Characteristics of the Filers

\section{(1)}

(2)

(3)

(4)

(5)

(6)

\begin{tabular}{|c|c|c|c|c|c|c|}
\hline \multirow[b]{2}{*}{$\begin{array}{l}\text { Dependent } \\
\text { Variable: }\end{array}$} & \multicolumn{3}{|c|}{$\begin{array}{r}\log \text { of } \\
\text { Liabilities-to. }\end{array}$} & \multicolumn{3}{|c|}{$\begin{array}{r}\text { Log of } \\
\text { Liabilities-to }\end{array}$} \\
\hline & $\begin{array}{r}\text { Log of } \\
\text { Liabilities }\end{array}$ & $\begin{array}{r}\text { Income } \\
\text { Ratio }\end{array}$ & $\begin{array}{l}\text { Log of } \\
\text { Income }\end{array}$ & $\begin{array}{c}\text { Log of } \\
\text { Liabilities }\end{array}$ & $\begin{array}{r}\text { Income } \\
\text { Ratio }\end{array}$ & $\begin{array}{l}\text { Log of } \\
\text { Income }\end{array}$ \\
\hline & \multicolumn{6}{|c|}{ A. 2001 Tax Rebates } \\
\hline After & 0.155 & 0.111 & 0.044 & 0.318 & 0.260 & 0.059 \\
\hline Check & $(0.045)$ & $(0.039)$ & $(0.028)$ & $(0.107)$ & $(0.084)$ & $(0.059)$ \\
\hline Sent & {$[0.001]$} & {$[0.005]$} & [0.119] & {$[0.003]$} & {$[0.002]$} & {$[0.317]$} \\
\hline \multirow[t]{2}{*}{$\mathrm{R}^{2}$} & 0.105 & 0.084 & 0.100 & 0.126 & 0.108 & 0.127 \\
\hline & \multicolumn{6}{|c|}{ B. 2008 Tax Rebates } \\
\hline After & -0.020 & 0.020 & -0.041 & -0.103 & -0.080 & -0.023 \\
\hline Check & $(0.053)$ & $(0.042)$ & $(0.030)$ & $(0.078)$ & $(0.066)$ & $(0.045)$ \\
\hline Sent & {$[0.702]$} & [0.630] & {$[0.175]$} & {$[0.186]$} & [0.228] & {$[0.601]$} \\
\hline After & 0.107 & 0.025 & 0.082 & 0.151 & 0.059 & 0.092 \\
\hline Direct & $(0.054)$ & $(0.043)$ & $(0.031)$ & $(0.210)$ & $(0.149)$ & $(0.151)$ \\
\hline Deposit & {$[0.048]$} & {$[0.566]$} & {$[0.009]$} & {$[0.472]$} & [0.693] & [0.541] \\
\hline Total & 0.086 & 0.045 & 0.041 & 0.048 & -0.021 & 0.069 \\
\hline \multirow[t]{2}{*}{ Effect } & $(0.032)$ & $(0.029)$ & (0.021) & $(0.227)$ & $(0.167)$ & $(0.160)$ \\
\hline & [0.007] & [0.126] & [0.046] & [0.832] & [0.901] & {$[0.667]$} \\
\hline $\mathrm{R}^{2}$ & 0.156 & 0.104 & 0.080 & 0.170 & 0.118 & 0.091 \\
\hline
\end{tabular}

Fixed Effects

SSN group FEs

Office FEs

Week FEs

$\begin{array}{cc}Y & Y \\ Y & Y \\ N & \text { N }\end{array}$

$\mathrm{Y}$
$\mathrm{Y}$
$\mathrm{N}$

$Y$
$Y$
$Y$

$\begin{array}{ll}Y & Y \\ Y & Y \\ Y & Y\end{array}$

Note: The sample consists of Chapter 7 filings randomly selected from ten court districts: 2,132 bankruptcies in 2001 and 4,355 bankruptcies in 2008. The standard errors in parentheses are robust to autocorrelation between observations from same SSN group, and associated p-values are in brackets. 